\title{
Covering International Marketing Influences on Firm International Performance: Evidences from GCC
}

\author{
Mansour S. M. Lotayif ${ }^{1}$ \\ ${ }^{1}$ Faculty of Commerce, Beni,Suef University, Egypt \\ Correspondence: Mansour S. M. Lotayif, Faculty of Commerce, Beni,Suef University, Egypt. E-mail: \\ Mansourlotayif@hotmail.com
}

Received: June 15, 2017

Accepted: July 15, 2017

Online Published: July 18, 2017

doi:10.5539/ijbm.v12n8p274

URL: https://doi.org/10.5539/ijbm.v12n8p274

\begin{abstract}
The current study aims at figuring out set of causality relationships with firm's international performance in GCC context. The experiences of 217 senior executives serving in Gulf region have been deployed for that purpose. Throughout SPSS version 21 and via multi-variant e.g. multiple regression and ANOVA, and bi-variant e.g. correlation, the current study's eight objectives and hypotheses were tested. The research results indicated that there are significant causality relationships between firm's international performance (FIP) and bi-marketing daily interaction, international marketing and general marketing coordination (IM-GM), international marketing influence, international learning orientation, international innovativeness orientation, and international entrepreneurial orientation, However, no significant causality relationship between study's demographics (i.e. business type, type of ownership, international experience, and number of employees) and FIP was revealed.
\end{abstract}

Keywords: firm international performance (FIP), international marketing (IM), general marketing (GM), international marketing influence, gulf cooperation council (GCC)

\section{Introduction}

Academically and practically international marketing (IM) importance is increasing by time. Academically, IM topics are part of the curriculum across business schools in most universities worldwide. Practically, companies seeking a strong completive advantage outside their own markets find international marketing a necessity for that particular mission (Paliwoda, 1999). Therefore, the more engagement of businesses beyond their borders by severing foreign markets the more the need for focusing on IM's role in these foreign markets. However, the development of IM as a literature stream is still lagging behind other traditional and classical marketing' areas (Cavusgil and Nevin, 1981). From the very beginning, we have to differentiate between IM and international business. The latter is touching everything in foreign markets but nothing in depth, and may include other managerial disciplines as well, such as human resource, finance, logistics etc (Paliwoda, 1999). In this perspective, Tesar (1984) have identified three main steps in international business: (1) studying carefully the foreign environment from all aspects; (2) taking the decision to cross the national boundaries to foreign markets; and (3) simultaneously selecting the appropriate marketing strategies for these foreign markets. The former represents all the activities belonging to marketing functions beyond domestic and national levels (Codita, 2011). To sum up, IM is the multi-national process of planning and executing the conception, prices, promotion and distribution of tangibles and intangibles offers via exchanges that satisfy the individual and organizational objectives (Czinkota and Ronkainen, 2012). In the current research the IM influences on firm's international performance (FIP) will be explored.

\section{Literature Review}

Nowadays there is a strong debate for the role of marketing function (MF), with its two wings i.e. domestic and international, for profit oriented businesses. As there are legitimate questions for its roles and participations could be raised and yet remained unanswered appropriately. These questions like: is the role declining or increasing? What is the importance of marketing in general and IM in particular for the firm's international performance? What are relationship consequences on international performance of both cooperative and ill-ease relationship's patterns between general marketing (GM) personnel and their colleagues in international marketing (IM) department? Having said that, the GM-IM relationship is still a debatable area of research. That debates could be centered around two literature's streams: (1) marketing function's importance (e.g. Engelen and 
Brettel, 2011; Merlo, 2011; Verhoef and Leeflang, 2009; O'Sullivan and Abela, 2007; Moorman and Rust 1999) and (2) international function (IM) role (e.g. Theodosiou and Leonidou, 2003; Verlegh and Steenkamp, 1999; Li and Cavusgil, 1995; Peterson and Jolibert, 1995; Albaum and Peterson, 1984; and Cavusgil and Nevin, 1981).

The second stream could be segregated into two main subgroups: (a) assessing the progress that have been made in international marketing in general (e.g. Li and Cavusgil, 1995; Albaum and Peterson, 1984; and Cavusgil and Nevin, 1981 ), and (b) discussing specific topics of international marketing, like country-of-origin effects (e.g. Verlegh and Steenkamp, 1999; and Peterson and Jolibert, 1995), adaptation and standardization of marketing strategy (e.g. Theodosiou and Leonidou, 2003), the effect of sizes on international marketing experiments (e.g. Wang and Yang, 2008), and exporting. (e.g. Aaby and Slater, 1989; Miesenbo"ck, 1988; and Bilkey, 1978). From that presentation it could be claimed that the role of IM and its influences on performance still in its enfant stage that needs more focus to explore that influences and the relationship with general marketing. The current study could be considered an endeavor in this perspective.

Generally, determining customers' needs and better satisfying these needs represent the main marketing aims to generate profit. The same aims are existed for international marketing but in determining of foreign markets needs for profit as well. Ghauri and Cateora (2011); Bradley (2005); Doole and Lowe (2008); Jain (1999); Paliwoda (1999); and Albaum and Peterson (1984) have been defined IM as the designed marketing activities crossing the nation's borders for satisfying customers/consumers needs abroad. Consequently, IM includes the followings; needs of different markets ought to be identified; competitive offers ought to be pledged to these culturally diversified markets; the delivery system for targeting these foreign markets ought to be tailored professionally; and keeping an imminent feedback system with effective tools for data collection, sorting, and analysis ought to be designed. The fact of the matter, IM tools extended beyond the regular design of 4P's/8P's concept to include topics such as legal environments, negotiation strategies, quality, costing and pricing for instance. Here and nowadays, effective international marketing activities are crucial for the success and prosperity of today's businesses working in a highly globalized and competitive economy (Czinkota and Ronkainen, 2007). It is argued that the growing globalization in recent decades could be responsible for the emergence of a new literature's stream of research focusing on international marketing activities and its importance at large. Literature wise, compared to domestic marketing knowledge, the field of IM has received relatively less focus and attention from marketing scholars and published articles at mainstream marketing journals (Leonidas and Bradley, 2010, Douglas and Craig, 1992; and Albaum and Peterson, 1984).

Stewart, 2002; Cavusgil, 1998; Farley and Wind, 1980; and Wind and Perlmutter, 1977) have been discussed the severe ramifications of such coverage's shortage on marketing context and theory. These ramifications are the existed scarcity of marketing studies for the effect of socio-cultural, political-legal, and economic systems prevailing in foreign markets on marketing activities. These ramifications reflected on consumer buying behavior, distribution structure, and sales force management. Also, too many untouched accumulated marketing problems, which related to the foreign environmental factors, are still existed such as foreign exchange effects on prices, political risk impact on business transactions, language influences on brand policy.

The gap in the international marketing literature has motivated Leonidas and Bradley (2010) to explore and classify the international marketing topics that have been published for 29 consecutive years (from 1975 to 2004) in top 10 ranked marketing periodicals (i.e. Journal of Marketing, Journal of Marketing Research, Journal of Consumer Research, Harvard Business Review, Management Science, Advances in Consumer Research, Marketing Science, Journal of the Academy of Marketing Science, Journal of Retailing, and Industrial Marketing Management). Their study aimed at: (1) revealing the length of involvement of top mainstream marketing journals in publishing international marketing topics; (2) better description of scholars publishing international marketing topics at these avenues; (3) evaluating the adopted methodology in these international marketing topics; and (3) creating a literature trend in this perspective. They confirmed the same conclusion of the relative scarcity of IM topics compared with local ones. In the same line of logic, Ali et al., (2014) confirmed the need for more international marketing focus instead of being domestically oriented only, as international marketing activities are crucial for the long term survival and continuity in markets.

Moreover, Omar (2008) discussed the activities of IM mix and classified them into: (1) analyzing current and potential markets' profitability and needs; (2) planning and designing the appropriate offer(s) that fit customers' needs in foreign markets, distinctly identified in a proper package; (3) selecting the appropriate distribution channel(s) that assure the services or conveniences required by current and potential customers; (4) selecting the appropriate international promotional mix and its components including advertising and personal selling to inform and educate consumers about current offers, or persuade consumers to try new, enhanced or different ways of satisfying their wants and needs;(5) the setting of prices that reflect both a reasonable value (or utility) 
of products or services to the consumers, and a satisfactory profit or return on investment; and (6) the technical and non-technical support given to customers, both before and after a sale is made, to ensure their satisfaction, and pave the way for possible potential sales that are necessary for company survival and growth.

In addition to that, Terpstra, (2000) argued regarding the international marketing role and importance in the current millennium by using what so called "future shock" as a new marketing terminology. In that future shock business environments are using terminologies like "globalization and global village" "global oligopolies", "technological changes", "aging demographic factor" and "political arena". He is claiming, globalization and global village will remain as ongoing business terminology as more firms tend to expand their business via the appropriate entry modes e.g. alliances, joint venture, acquisitions etc. Many scholars in entry modes' literature have participated massively in choosing the appropriate entry modes that fits the market characteristics (e.g. Lotayif, 2005 and 2004; Pan and Tse 2000, Terpstra and Sarathy, 1991, and Dahringer and Muhlbacher, 1991).

In global oligopolies there is a high probability for creating few large players seeking the dominance of business markets. The status quo in mobile phone, petroleum, hotel, and car industries, for instance, are clear examples in this perspective nowadays. Technological changes represent another challenging component of the future shock with its massive consequences on IM activities. Aging demographic factor represents the changing of markets characteristics and importance that impose massive changes in the adopted marketing mix components (i.e. four P's and eight P's) to better satisfy markets needs. Finally, the political arena is a crucial dimension in the future shock as the cohesiveness of current trading blocs e.g. EU, NAFTA, Mercsour, and GCC might be affected. Cases like UK exit from EU, USA ill-ease status with NAFTA agreement, and sanctions against Qatar from other GCC members are pretty clear examples in this perspective. Annex, the future political trend imposes a very legitimate query regarding the level of cooperation or confrontation amongst countries worldwide. Scattered small wars here and there are pretty clear examples in this perspective and their ramifications on IM and business environment at large yet unclear.

Gnizy and Shoham, (2014) have been touched the international marketing activities from different angle. They did introduce a model explaining the relationship between international marketing (IM) and general marketing (GM), and the ramifications of that particular relationship on firm's international performance a logic that was adopted in the current study with some amendments for the suggested model at large. More specifically, the current suggested model is deploying Gnizy and Shoham's variables differently, as it explores the causality relationships amongst these variables and the firm international performance (FIP) a practice which not followed at Gnizy and Shoham's study. As presented in Figure (1), the suggested model's eight-parts are demographics, bi-marketing interactions, coordination between IM and GM, IM influences on performance, international learning orientation, international innovativeness orientation, international entrepreneurial orientation, and international business performance. 


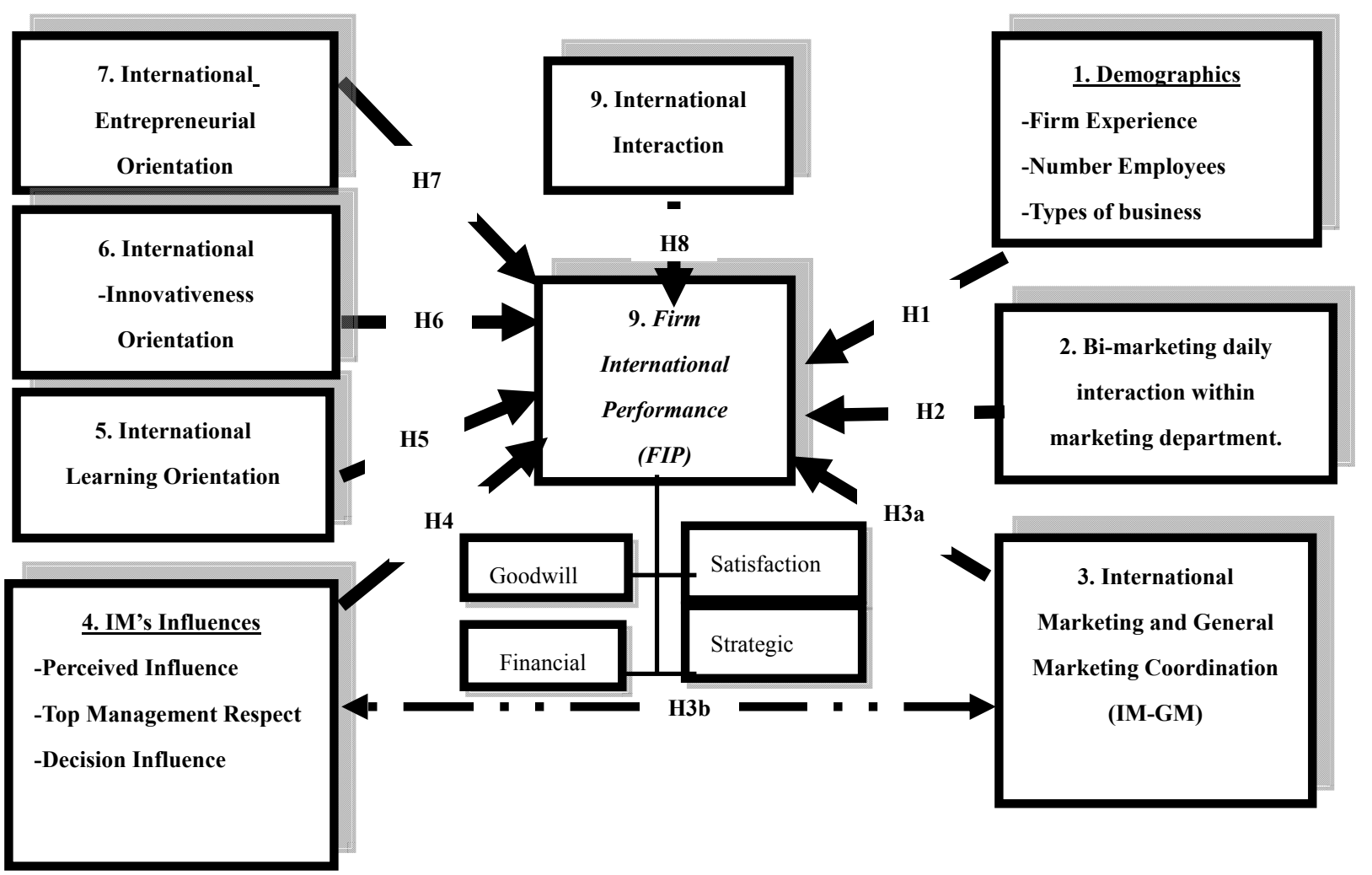

Figure 1. Suggested model's variables

Source: (Most of the main variables) - adapted from Gnizy and Shoham, (2014).

First, it worth mentioning that companies with IM activities could organize their structures according to the length of marketing activities, years of experience in foreign markets, and company's size (Calantone et al., 2002; Sinkula, 1994; and Samiee and Walters, 1990). More specifically, Samiee and Walters, (1990) argued that large companies are using mainly "export-specific structures" through internal-professional team. Calantone et al., (2002); Sinkula, (1994) argued around the learning curve in foreign markets and its ramifications on international performance. Having said that, the model demographical variables are international experience (measured by number of years in foreign markets), number of employees, firm size i.e. large small, and medium, types of business i.e. commercials, industrials, and services, and types of ownership i.e. private and public (Lotayif, 2017\& 2004; Gnizy and Shoham, 2014; Calantone et al., 2002; Samiee and alters; 1990; and Sinkula, 1994). Secondly, the daily interaction between local marketing and export personnel teams is crucial for the international performance. Narver and Slater (1990) measured that interaction's concept via five items: interfunctional customer calls; information shared among functions; functional integration in strategy; contribution to customer value; and sharing resources with other business units, a practice that followed in the current research.

Thirdly, IM-GM coordination descripts the day-to-day interactions amongst personnel in homogeneous team. Literally, a team is a group of individuals that works to achieve organizational aims interdependently, and shares responsibility for team performance (Robin et al., 2008, and Cohen and Bailey 1997). That coordination reflects on the way of using the marketing capabilities in local and foreign markets. Such capabilities include skills, knowledge for markets, customers, and competition in local and foreign markets to enhance the overseas marketing decisions and performance either directly and indirectly (Verhoef and Leeflang, 2009; Blesa and Ripolles, 2008, Griffin and Hauser, 1996; and Day, 1994). Gnizy and Shoham, (2014) have been considered coordination with general marketing efforts as an element of international marketing interaction's capabilities. Cadogan et al., (2005) have been argued regarding the effect of positive cooperation and interaction on international goals' achievement level. Verhoef and Leeflang (2009) did define marketing cooperation as the degree of unit-to-unit communication, unit-to-unit collaboration, and unit-to-unit cooperative relationships, here, it could be considered as an influence's driver.

To deal with turbulent marketing environment coupled with numerous and sometimes endless customers needs nowadays, Cadogan et al., (2005) stated the fronts of inner cooperation (i.e. IM-GM interaction and cooperation). 
These fronts of cooperation include standardization or adaptation (i.e. levels and depth), the perception of country-of-origin and its effects on sold offers, and feedbacks from foreign markets necessitate the frequent communications with local marketing personnel. Inevitably, IM-GM coordination ought to be stressed if ambitious objectives ought to be reached. However, IM-GM conflict might happen due to goals' incompatibility, expectations, and actions. This might harm firm's efficiency, in general, and marketing performance in foreign marks, in particular, as it affects negatively the inflow of knowledge, ideas, and innovation from overseas markets (Harris et al., 2008; Cadogan et al., 2005; and Bennett and Savani, 2004). Gnizy and Shoham, (2014) claimed that IM-GM conflicts might lead to reduce IM's influence at large.

Fourth, international marketing (IM) influence comes from marketing influence that in turn comes from market or strategic orientation of firms. More specifically, the more strategic oriented the firm has, the more marketing influences existed and the more performance enhancement the firm could achieve and vice versa (Gnizy and Shoham, 2014). Verhoef and Leeflang, (2009); Lotayif, (2004); Baker and Sinkula, (1999); and Cadogan et al., (1999) have argued regarding the relationship between orientation and performance. As strategic orientations might pledge the firm with many things. It could provide with behavioral norms for actions homogeneity. It could provide with direct resources for acquisition either partially or fully to strengthening the existed capabilities and creating new advantages. Also, it could provide with appropriate guidance for firm's operations to better achieve goals. And eventually strategic orientation is positively affecting firm's performance. Therefore, it is like the spiritual mode that has its positive ramifications, if followed, on performance (Papadopoulos and Martı'n, 2010; Sousa et al., 2008; Kim et al., 2003). However, marketing influences-performance's literature has few contradictory results in this perspective. More specifically, Verhoef et al., (2011); and Moorman and Rust, (1999) claiming positive relationship between these two variables but Merlo and Auh, (2009); Verhoef and Leeflang, (2009) did not approve such relationship, for instance. Consequently, this relationship will be examined in the current research.

Fifth, in international marketing literature, international orientation could be measured via three main concepts: market, entrepreneurial, and innovativeness (e.g. Gnizy and Shoham, 2014; Dimitratos and Plakoyiannaki, 2003, and Cadogan et al., 1999). The first concept which is international market orientation represents the actions taken to give foreign markets much more professional interests and resources. That orientation could be perceived as an adopted posture to create value to overseas markets that reflected on export intelligence generation, dissemination, and responsiveness (Dimitratos and Plakoyiannaki, 2003, and Cadogan et al., 1999). Gnizy and Shoham, (2014) argued that international marketing's influence antecedes international market orientation, which in turn is related to performance. Here the logic supporting this argument is the inclusiveness of MFs to IM and marketing concept is associated with MFs. Consequently, it would be surprising if IM is not affecting international market orientation. That logic is accepted, adopted, and will be tested in the current research.

For the second international orientation's concept, which is entrepreneurial orientation, has been viewed as proactive, innovative, risk-taking ideology, cross national exploitation of market opportunities via designing and developing new commodities, services, and ideas for these particular foreign markets (Gnizy and Shoham, 2014; Oviatt and McDougall, 2005; Slater and Narver, 1995; and Covin and Slevin , 1991). In international marketing literature, there is a stream of literature that stressing the link between entrepreneurship, marketing functions' influences, markets' cultures and performance (e.g. Sepulveda, 2010; Verhoef and Leeflang, 2009; Hult et al., 2003; Morris et al., 2002; Knight, 2001; and Hills, 1999). For instance, Hills, (1999) viewed marketing functions' influence and entrepreneurial orientations are intertwined. When merging the two marketing jargons: entrepreneurial orientation and marketing together we get what so called "entrepreneurial marketing". That entrepreneurial marketing is the combination of crucial marketing aspects and entrepreneurship aspects in one united terminology. Also, entrepreneurial orientations and performance relationship will be addressed in the current research.

For the third international orientation's concept, which is innovativeness, could be considered very crucial for organizations to live and grow. It represents the power for adding up new offers or changing the existed ones to gain competitive advantages in foreign markets (Gnizy and Shoham, 2014). So it represents the power for changing the status quo. Based on the research and development's budget the organization has and technological novelty the organization introduces, organizations' innovativeness status could be assessed (Gnizy and Shoham, 2014). Sepulveda, (2010); Verhoef and Leeflang, (2009); Shoham et al., (2008); and Menon et al., (1999); have been argued regarding the meaning of innovativeness. It might include the venerability for change via more leniencies for experiment and offering new ideas for new and existed markets. Inevitably, it assumes adopting high level of creativity, risk-taking, future orientation, and proactiveness. Therefore, practicing that level of 
innovations in what so called "commercializing innovation" will have positive ramifications on firm's performance (Kirbach and Schmiedebery, 2006; Dimitratos and Plakoyiannaki, 2003; and Guan and Ma, 2003). Therefore, the relationship between "commercialized innovation" or "innovativeness orientation" and performance will be part of the study objectives' bundle.

Finally, performance's literature has diversity of measuring tools for organizational performance (OP). Gnizy and Shoham, (2014); Collins and Clark, (2003); ; Collins and Clark, (2003); Anderson and Reeb, (2003); Richard and Johnson, (2001); Richard and Johnson, (2001); Cappelli and Neumark, (2000); Bae and Lawler, (2000); Lee and Miller, (1999); Lam and White, (1998); Zou et al., (1998); Lam and White, (1998); d'Arcimoles, (1997); Huselid, et al.,(1997); Montemayor (1996); Delery and Doty, (1996); Lee and Chee, (1996); Huselid, (1995); Dechow, (1994); and Yutchman and Seashore, (1967) have been measured performance via financial way, strategic way, earnings, customer satisfaction, customer retention, productivity, public image and goodwill, internal and external resources utilization, gross rate of return on assets, return on assets and return on equity, stock market value, net income per employee, turnover included both voluntary and involuntary departures, labor productivity, fulfilling both internal and external stakeholders' needs; profitability, sales growth, and quality. As the current research is focusing on international performance, firm's, financial status (measured by profitability), image and goodwill (measured by 3 items), customer satisfaction (measured by three items), and strategic performance (measured by 5 items).are viewed as appropriate tools for performance's measuring, as in appendix (B).

\section{Study Objectives}

\section{In GCC context the following objectives will be tested:}

1. Examining the relationship between firm's demographics and firm international performance ( $\underline{\text { FIP }}$ )

2. Examining the relationship between bi-marketing interaction between export (IM) and local marketing $(\mathrm{GM})\}$ and firm international performance (FIP).

3. Examining the relationship between $\underline{\mathbf{I M}-\mathbf{G M}}$ cooperation and firm international performance $(\underline{\mathbf{F I P}})$..

4. Examining the relationship between $\underline{\mathbf{I M} \text { influences and firm international performance (FIP) }}$

5. Examining the relationship between international learning orientation and firm international performance ( $\underline{\text { FIP }})$,

6. Examining the relationship between international innovativeness orientation and firm international performance ( $\underline{\text { FIP }})$

7. Examining the relationship between international entrepreneurial orientation and firm international performance ( $\underline{\text { FIP }})$

8. Examining the relationship between international interaction and firm international performance (FIP)

\section{Study Hypotheses}

To achieve the above mentioned objectives, the following relationships are proposed.

H1: "There is a significant causality relationship between firm's demographics and firm international performance (FIP)".

H2: "There is a significant causality relationship between bi marketing interaction and firm international performance ( FIP)".

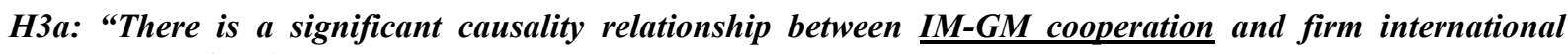
performance (FIP)".

\section{H3b: "There is a significant causality relationship between IM-GM cooperation and IM influence"}

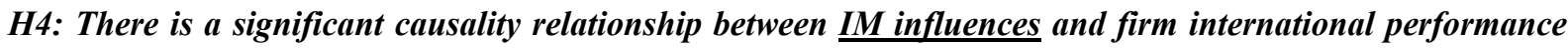
(FIP)".

H5: "There is a significant causality relationship between international learning orientation and firm

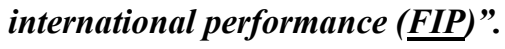

H6: "There is a significant causality relationship between international innovativeness learning orientation and firm international performance (FIP)".

H7: "There is a significant causality relationship between international entrepreneurial orientation and firm international performance (FIP)". 


\section{H8: Examining the relationship between international interaction and firm international performance (FIP)}

\section{Research Methodology}

In this part of the research, the study's paradigm, population from which the representative sample was taken, sample type, ways used for data collection, analytical package used, techniques of statistical analyses will be discussed appropriately. For research paradigm, quantitative approach through using a structured questionnaire was used. The respondents were senior executives accountable for or participated at international decisions recently i.e. the last two years, as clearly stated in the cover letter attached. International experience was stated as a prerequisite for eligibility to answer the questionnaire otherwise to be directed to the authorized executive. The targeted firms or "qualified companies" are those with separate local and international operations. The company online organizational structures were used to accomplish this point. For sample type, size, and response rate, a convenience sample sized 217 senior executives operating in Gulf region has been used in the current study with 72.3 percent response rate as 300 questionnaires were mailed and 217 questionnaires were completed and returned. Throughout their emails, those 300 senior executives, marketing managers, and general managers in Gulf market were targeted and were given other reminding messages after fifteen days. For data collection way, ten-concept structured questionnaire with Lickert five-point scale was used, as described in Appendix (B). After the cover letter that clarifies the research objectives and eligibility to answer, the questionnaire begins by four demographics e.g. business type, ownership type, international business experience, and company size. The questionnaire's ten concepts are marketing bi-functional interactions (X1) from X2 to X6, IM-GM coordination (X7) from X8 to X14, IM influence (X15) from X16 to X19, top management respect (X20) from X21 to X23, decision influence (X24) from X25 to X28, international orientations (X29) from X30 to X42, innovativeness (X43) from X44 to X48, entrepreneurial (X49) from X50 to X53, learning (X54) from X55 to X 58, and international performance (X59) that measured via four sub-concepts i.e. financial (X60), strategic (from X61 to $\mathrm{X} 65)$ and averaged by (X61n) to be utilized as DV in multiple regression equation, customer satisfaction (from X66 to X 68) and averaged by (X66n), and goodwill (from X69 to X71) and averaged by (X69n). For the analytical statistical package, SPSS version twenty one was deployed for that purpose. Bi-variant i.e. correlation, and multi-variant analysis (e.g. multiple regression and ANOVA) were deployed as analytical techniques in the current research.

\section{Study Findings}

In this part, normality, multi-collinearity, validity, reliability, hypotheses testing, results discussions, conclusion and recommendations will be stressed.

\subsection{Normality, Regressors Multi-Collinearity, Scale Validity, and Reliability}

Statisticians indicated that data distribution's shape could be assumed normal whenever the sample size is more than thirty cases (e.g. Ortuzar and Willumsen, 1994). Therefore, normality dimension is assumed, as sample's size is 217 respondents in the current study. Also, reliability condition is met as Cronbach alpha coefficients showed values greater than 0.60 with all concepts (e.g. Lotayif, 2016; Francis, 2001, and Robinson et al., 1991). As in Table (2), Cronbach values are 96.9, 92.7, 76.1, 81.9, 64.5, 79.6, 90.1, 82.5, 85.4, 84.7, and 93.6 percent for the whole instrument (excluding demographical variables) and for each consecutive concept i.e. marketing bi-functional interactions, IM-GM coordination, IM influence, top management respect, decision influence, international orientations, innovativeness, entrepreneurial, learning, and international performance respectively. consequently, reliability condition in the current study is supported. Multi-collinearity amongst study's regressors including demographics (excluding international performance as it function as DV in the current study) are supported, as all correlations' values are less than unity, as indicated in Tables (3-9).

Table 2. Study Cronbach values

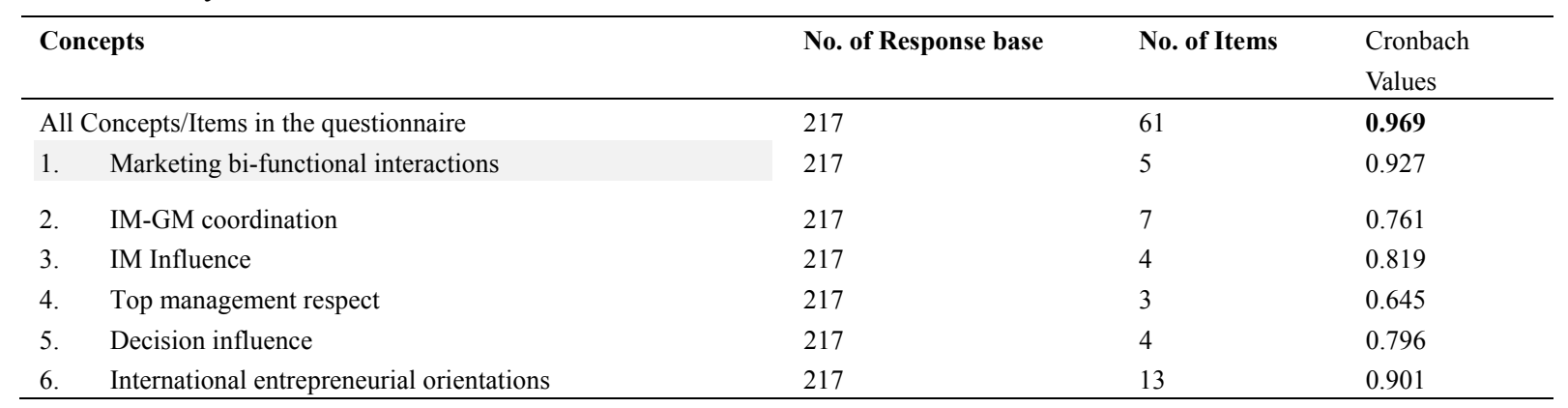




\begin{tabular}{lllll}
\hline 7. & Innovativeness & 217 & 5 & 0.825 \\
8. & Interaction & 217 & 4 & 0.854 \\
9. & Learning & 217 & 4 & 0.847 \\
10. & International Performance & 217 & 12 & 0.936 \\
\hline
\end{tabular}

Table 4. Multi-collinearity of Marketing bi-Functional Table 3. Multi-collinearity of Demographics as Interaction as Regressors Regressors

\begin{tabular}{|c|c|c|c|c|c|c|c|c|c|c|}
\hline & 2 & 3 & 4 & 5 & 6 & & BUS & OWN & EXP & SIZE \\
\hline $\mathrm{X} 2$ & ..... & & & & & BUS & ..... & & & \\
\hline $\mathrm{X3}$ & 0.662 & ..... & & & & OWN & 0.009 & ..... & & \\
\hline $\mathrm{X4}$ & 0.461 & 0.476 & ..... & & & EXP & 0.023 & 0.170 & ..... & \\
\hline X5 & 0.489 & 0.481 & 0.434 & ..... & & SIZE & 0.060 & 0.056 & 0.505 & ..... \\
\hline X6 & 0.272 & 0.341 & 0.233 & 0.399 & ...... & $>$ & $=6\} \mathrm{cel}$ & & & \\
\hline
\end{tabular}

Note: - Matrix's cells $=\mathrm{n}(\mathrm{n}-1) / 2,\{5(5-1) / 2=10$ cells. - All Xs meanings as in Appendix B.

Table 5. Multi-collinearity of IM-GM Coordination as Regressors Table 6. Multi-collinearity of IM Influences as Regressors

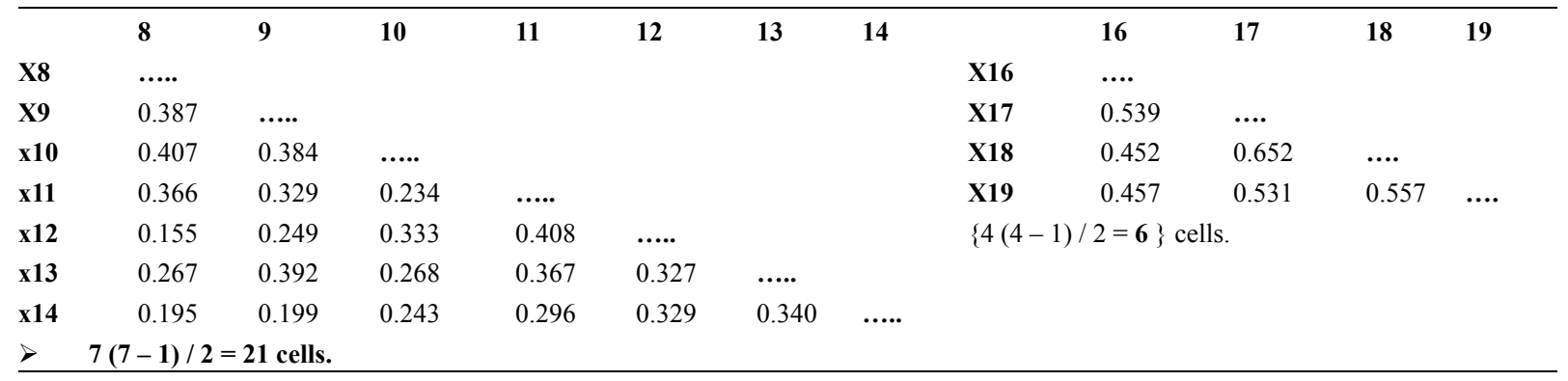

Table 7. Multi-collinearity of Table 8. Multi-collinearity ofTable 9. Multi-collinearity of Innovativeness as Regressors Interaction as Regressors Learning as Regressors

\begin{tabular}{|c|c|c|c|c|c|c|c|c|c|c|c|c|c|c|c|}
\hline & 44 & 45 & 46 & 47 & 48 & & 50 & 51 & 52 & 53 & & 55 & 56 & 57 & 58 \\
\hline $\mathrm{x} 44$ & $\ldots .$. & & & & & $\times 50$ & $\ldots .$. & & & & $\mathrm{x} 55$ & $\ldots .$. & & & \\
\hline $\mathrm{x} 45$ & .623 & $\cdots .$. & & & & $\mathrm{x} 51$ & .606 & .... & & & $\mathrm{x} 56$ & .683 & ..... & & \\
\hline $\mathrm{x} 46$ & .544 & .543 & ..... & & & $\mathrm{x} 52$ & .548 & .684 & $\ldots .$. & & $\mathrm{x} 57$ & .487 & .652 & $\ldots .$. & \\
\hline $\mathrm{x} 47$ & .483 & .510 & .497 & $\ldots .$. & & $\mathrm{x} 53$ & .513 & .559 & .704 & $\ldots .$. & $\mathrm{x} 58$ & .463 & .601 & .593 & $\ldots .$. \\
\hline $\mathrm{x} 48$ & .363 & .316 & .481 & .537 & $\ldots .$. & $>$ & \multirow{2}{*}{\multicolumn{3}{|c|}{$4(4-1) / 2=6$} cells } & & $>$ & \multicolumn{4}{|c|}{$4(4-1) / 2=6$} cells. \\
\hline$>$ & $\{5(5-$ & $/ 2=10$ & cells. & & & & & & & & & & & & \\
\hline
\end{tabular}

Table 10. Multi-collinearity of International Entrepreneurial Orientation as Regressors

\begin{tabular}{|c|c|c|c|c|c|c|c|c|c|c|c|c|}
\hline 30 & 31 & 32 & 33 & 34 & 35 & 36 & 37 & 38 & 39 & 40 & 41 & 42 \\
\hline \multicolumn{13}{|l|}{..... } \\
\hline .633 & ..... & & & & & & & & & & & \\
\hline .473 & .614 & $\ldots .$. & & & & & & & & & & \\
\hline .330 & .457 & .564 & ..... & & & & & & & & & \\
\hline .337 & .476 & .486 & .488 & $\ldots .$. & & & & & & & & \\
\hline .360 & .484 & .471 & .480 & .549 & ..... & . & & & & & & \\
\hline .308 & .459 & .486 & .367 & .495 & .572 & ..... & & & & & & \\
\hline .398 & .450 & .457 & .338 & .335 & .420 & .564 & ..... & & & & & \\
\hline .320 & .376 & .437 & .354 & .261 & .366 & .490 & .521 & $\ldots .$. & & & & \\
\hline .398 & .460 & .353 & .296 & .420 & .464 & .491 & .498 & .483 & ..... & & & \\
\hline .295 & .349 & .349 & .346 & .296 & .402 & .333 & .383 & .288 & .458 & $\ldots .$. & & \\
\hline .317 & .387 & .490 & .373 & .337 & .355 & .377 & .397 & .377 & .412 & .527 & $\ldots .$. & \\
\hline .308 & .366 & .400 & .315 & .405 & .377 & .375 & .328 & .350 & .449 & .504 & .591 & ..... \\
\hline$>$ & \multicolumn{12}{|c|}{$13(13-1) / 2=78$} cells. \\
\hline
\end{tabular}


For questionnaire's validity, grouped discussions with colleagues and fellow academics suggested some minor paraphrasing and typo changes to adapt the questionnaire with gulf culture were conducted. Statistically, scale's validity is the degree to which a test measures the concept(s) that it claims measuring (e.g. Lotayif, 2015a, 2015b, 2014; and Nunnally, 1978). There is no common test for scale's Validity (Kline, 1997). Stodnick et al., (2008); Saravanan et al., (2007); Lotayif, (2004); and Keil et al., (2000) have discussed the validity concept. These types are face, contents, predictive (criterion-related validity), construct, concurrent, convergent, divergent, and discriminant validities.

Firstly, face validity illustrate the appropriateness level of questionnaire to its aims. Therefore, it explains everything related to collecting the required data for the intended objectives. More specifically, from questions design and order, to number of questions to be taken, to number of constructs to be included in the instrument, to number of items within each concept, to editing typo and grammatical mistakes etc. The appropriate way for measuring such type of validity could be the pilot study mechanism for experts' opinions and feedbacks. Consequently, it is judgmental in nature and might differ from research to another. (Lotayif, 2017; 2016). Secondly, content validity explains the appropriate coverage of the topics being researched (Rust and Golomok, 1999). To assure face and content validities, the research's questionnaire was reviewed by fellow academics for consultation and industry experts for better alignment with gulf perceptions. Then the research's questionnaire was amended and refined accordingly. As the current study is using almost a ready-made questionnaire, some minor amendments have been taken in this perspective. Thirdly, construct validity illustrates the level of construct(s) appropriateness for usage (Bryman and Cramer, 1999). As the instrument is made of eleven well know constructs (e.g. Wong, and Merrilees, 2007), construct validity and all other types of validities are supported.

\subsection{Testing Research Hypotheses}

As indicated in Table (11), there is no significant causality relationship between firm's international performance (FIP) and demographics as $p$ values equal $0.576,0.249,0.367$, and $0.149 \geq 0.05$. Therefore, hypothesis $(\boldsymbol{H} 1)$ is not supported. Consequently, firms' international performances (FIPs) are not affected by type of business if it's commercial, industrial, or service. Also, the type of ownership does not affect FIPs, as it does not matter if the business is privately or publicly owned and operated. As well as, how long or how short international business experience the firm has does not affect its FIP. Finally, how big-size or how small-size the business is does not affect its FIP. Therefore, other variables rather than these demographical ones have the significant influences on FIP in the current study.

Statistically, the existence of model causality relationship does not guarantee the existence of significant relationships between all IVs components and the dependent variable (DV). But it does guarantee only the existence of at least one significant relationship (Lotayif, 2004, p. 261). Using the same line of logic, it could be concluded that if there is no significant causality relationship reported, this means no single variable has a significant relationship with the DV. Therefore, checking coefficient values (i.e. $B$ and $P$-values) help clarify the real relationships between any set of variables as IVs and the dependent variable (DV). As shown in Table (12) all $P$-values reported values more than 0.05 which confirms there is no relationship between FIP with its four sub indicators (i.e. goodwill, strategic, financial, and customer satisfaction) and study's demographics i.e. business type, ownership type, business experience, and firm size.

Table 11. Multiple Regressions between Firm International Performance (FIP) (as DV) measured by Goodwill, Strategic, Financial, and Satisfaction and Demographics, (as, IVs)

\begin{tabular}{|c|c|c|c|c|c|c|}
\hline DVs and IVs List & $\begin{array}{l}\text { F } \\
\text { values } \\
\end{array}$ & P-values & $\mathbf{R}$ & R Square & $\begin{array}{l}\text { Adjusted R } \\
\text { Square }\end{array}$ & $\begin{array}{l}\text { Durbin- } \\
\text { Watson }\end{array}$ \\
\hline Performance (via Goodwill) * Demographics & 0.724 & 0.576 & 0.116 & 0.013 & 0.005 & 1.156 \\
\hline Performance (via Strategic) $*$ Demographics & 1.359 & 0.249 & 0.158 & 0.025 & 0.006 & 1.189 \\
\hline Performance (via Financial) $*$ Demographics & 1.079 & 0.367 & 0.141 & 0.019 & 0.001 & 1.574 \\
\hline Performance (via Customer Satisfaction ) * Demographics & 1.708 & 0.149 & 0.176 & 0.031 & 0.012 & $\begin{array}{r}1.387 \\
\text { Notes:- }\end{array}$ \\
\hline \multicolumn{7}{|l|}{$>$ Significant relationships are reported as $p \leq 0.05$. } \\
\hline \multicolumn{7}{|c|}{$>\quad$ R Square $=$ indicates magnitude of the IVs effect on the DV in the sample. } \\
\hline \multicolumn{7}{|l|}{ a } \\
\hline Durbin-Watson is a test to indicate the effect of data & try order & he analysis & tat grap & s 2000). & & \\
\hline
\end{tabular}


Table 12. ANOVA Coefficient's Values of Demographics and FIP

\begin{tabular}{llllllllll}
\hline Goodwill & BUS & Own & Experience & Size & Strategic & BUS & Own & Experience & Size \\
\hline B Value & 0.079 & 0.038 & 0.032 & 0.108 & B Value & 0.073 & 0.060 & 0.022 & 0.088 \\
$\boldsymbol{P}$-Value & 0.270 & 0.769 & 0.529 & 0.192 & $\boldsymbol{P}$-Value & 0.210 & 0.571 & 0.594 & 0.198 \\
Financial & BUS & Own & Experience & Size & Satisfaction & BUS & Own & Experience & Size \\
B Value & 0.08 & 0.030 & 0.042 & 0.156 & $\boldsymbol{B}$ Value & 0.022 & 0.057 & 0.049 & 0.098 \\
$\boldsymbol{P}$-Value & 0.247 & 0.825 & 0.432 & 0.077 & $\boldsymbol{P}$-Value & 0.712 & 0.592 & 0.246 & 0.157 \\
\hline
\end{tabular}

In Table 13 there is a significant causality relationship between firm international performance (FIP) and bi-marketing daily interaction as $P=0.000 \leq 0.05$. Therefore, hypothesis $(\boldsymbol{H} 2)$ is supported. In this perspective, the most remarkable things here are:

- The order of data entry process did not affect on its analysis, as Durbin-Watson test showed values $>$ 1.4 with all dependent variables, as shown in Table (13).

- The explanation powers of bi-marketing interaction's magnitude on the four sub-performance indicators i.e. firm's goodwill, strategic performance, financial performance, and customer satisfaction are low as " $R$ square" and "adjusted $R$ square" reported values less than 50 percent. These values are 19.1, 31.4, 12.4, and 29.4 percent and 17.2, 29.8, 10.3, and 27.7 percent for " $R$ square" and "adjusted $R$ square" respectively. Consequently, bi marketing daily interaction affects more on strategic performance (adjusted R square $=29.8$ percent) and least on financial performance (adjusted $\mathrm{R}$ square $=10.3$ percent). More specifically and using ANOVA coefficient values as in Table (14), interfunctional customer calls (X2) and share resources with other business units (X5) are the two items within bi marketing concept that have reported significant relations with strategic performance (as $\boldsymbol{B}$ value $=0.315$, and 0.252 and $\boldsymbol{P}$-values $=0.000$ and $0.000 \leq 0.05$ ). Also, the same two items i.e. X2 and X5 affect financial performance (as $\boldsymbol{B}$ value $=0.155$ and $0.161 \boldsymbol{P}$-values $=0.000$ and 0.000 $\leq 0.05$ ). For goodwill, (X2), (X5) and (X4 i.e. functional integration in strategy) within bi marketing items have reported significant relationships with goodwill (as $\boldsymbol{B}$ values $=0.199,0.254$, and 0.172 and $\boldsymbol{P}$-values $=0.031$, 0.006 , and $0.017 \leq 0.05$ ). For customer satisfaction, the same two bi marketing items i.e. (X2), and (X5) have reported significant relationships with customer satisfaction (as $\boldsymbol{B}$ values $=0.341$, and $0.286 \boldsymbol{P}$-values $=0.000$ and $0.000 \leq 0.05)$.

Table 13. Multiple Regressions between Firm International Performance (FIP) (as DV) measured by Goodwill, Strategic, Financial, and Satisfaction and Bi-Marketing Interaction, (as, IVs)

\begin{tabular}{lllllll}
\hline DVs and IVs List & F & P-values & R & R Square & $\begin{array}{l}\text { Adjusted R } \\
\text { Square }\end{array}$ & $\begin{array}{l}\text { Durbin-W } \\
\text { atson }\end{array}$ \\
\hline Performance (via Goodwill) * Bi Marketing & 9.970 & $\mathbf{0 . 0 0 0}$ & 0.438 & 0.191 & 0.172 & 1.543 \\
Performance (via Strategic) * Bi Marketing & 19.298 & $\mathbf{0 . 0 0 0}$ & $\mathbf{0 . 5 6 1}$ & $\mathbf{0 . 3 1 4}$ & $\mathbf{0 . 2 9 8}$ & 1.619 \\
Performance (via Financial) * Bi Marketing & 5.956 & $\mathbf{0 . 0 0 0}$ & 0.352 & 0.124 & $\mathbf{0 . 1 0 3}$ & 1.651 \\
Performance (via Customer Satisfaction) * Bi Marketing & 17.537 & $\mathbf{0 . 0 0 0}$ & 0.542 & 0.294 & 0.277 & 1.876 \\
\hline
\end{tabular}

Table 14. ANOVA Coefficient's Values of Bi-Marketing Interaction and FIP

\begin{tabular}{|c|c|c|c|c|c|c|c|c|c|c|c|}
\hline Goodwill & 2 & 3 & 4 & 5 & 6 & Strategic & 2 & 3 & 4 & 5 & 6 \\
\hline \multirow{2}{*}{$\begin{array}{l}\text { B Value } \\
P \text {-Value }\end{array}$} & 0.199 & 0.017 & 0.172 & 0.254 & \multirow{2}{*}{$\begin{array}{l}0.047 \\
0.457 \\
\end{array}$} & \multirow{2}{*}{$\begin{array}{l}\text { B Value } \\
P \text {-Value }\end{array}$} & 0.315 & \multirow{2}{*}{$\begin{array}{l}0.014 \\
0.832 \\
\end{array}$} & \multirow{2}{*}{$\begin{array}{l}0.061 \\
0.259 \\
\end{array}$} & 0.252 & \multirow{2}{*}{$\begin{array}{l}0.082 \\
0.092 \\
\end{array}$} \\
\hline & 0.031 & 0.848 & 0.017 & 0.006 & & & 0.000 & & & 0.000 & \\
\hline Financial & 2 & 3 & 4 & 5 & 6 & Satisfaction & 2 & 3 & 4 & 5 & 6 \\
\hline \multirow{2}{*}{$\begin{array}{l}\text { B Value } \\
P \text {-Value }\end{array}$} & 0.155 & 0.1207 & 0.096 & 0.161 & \multirow{2}{*}{$\begin{array}{l}0.069 \\
0.750\end{array}$} & \multirow{2}{*}{$\begin{array}{l}\text { B Value } \\
P \text {-Value }\end{array}$} & 0.341 & 0.069 & 0.054 & 0.286 & 0.066 \\
\hline & 0.000 & 0.539 & 0.935 & 0.000 & & & 0.000 & 0.339 & 0.335 & 0.000 & 0.190 \\
\hline
\end{tabular}

$>$ Note: $2-6=$ X2-X6 items as appeared in Appendix (B)

In Table (15) there is a significant causality relationship between firm international performance (FIP) and international marketing (IM) and general marketing IM-GM coordination as $P=0.000 \leq 0.05$. Therefore, hypothesis $(\boldsymbol{H} \mathbf{3} \boldsymbol{a})$ is supported. In this perspective, the most remarkable things here are:

- The order of data entry process did not affect on its analysis, as Durbin-Watson test showed values $>$ 1.4 with all dependent variables, as shown in Table 15. 
- The explanation powers of IM-GM coordination magnitude on the four sub-performance indicators i.e. firm's goodwill, strategic performance, financial performance, and customer satisfaction are low as " $R$ square" and "adjusted $R$ square" reported values less than 50 percent. These values are 14.0, 24.8, 16.4, and 18.6 percent and 11.1, 22.3, 13.6, and 15.9 percent for " $R$ square" and "adjusted $R$ square" respectively. The highest causality magnitude of the DV i.e. IM-GM coordination exists with strategic performance (as adjusted $R$ square $=23.3$ percent) and least exists with customer satisfaction (as adjusted $R$ square $=15.9$ percent).

- More specifically and using ANOVA coefficient values as in Table (16), firm's goodwill is affected by only one item $\{$ i.e. these functions get along well with each other $(\mathrm{X} 8)\}$ out of seven items of IM-GM coordination concept as $\boldsymbol{B}=0.169$ and $\boldsymbol{P}$-value $=0.036 \leq 0.05$ ). Also, strategic performance is affected by two items \{i.e. these functions get along well with each other (X8), and employees from these functions feel that the goals of their respective functions are in harmony with each other. (X11) $\}$ out of the seven items of IM-GM coordination concept, as $\boldsymbol{B}=0.204$, and 0.166 and $\boldsymbol{P}$-value $=0.001$, and $0.019 \leq 0.05$ ). For Financial performance only two items out of seven i.e. people in one function generally like interacting with those from other function (X10) and the objectives pursued by one function are compatible with those of the other function (X13) reported significant relationships with IM-GM concept as $\boldsymbol{B}=0.187$, and 0.281 and $\boldsymbol{P}$-value $=0.031$, and $0.000 \leq 0.05$ ). Finally, only one item out of seven $\{$ i.e. employees from these functions feel that the goals of their respective functions are in harmony with each other (X11)\} reported significant relationship with customer satisfaction as $\boldsymbol{B}=0.150$ and $\boldsymbol{P}$-value $=0.047 \leq 0.05$ ).

Table 15. Multiple Regressions between Firm International Performance (FIP) (as DV) measured by Goodwill, Strategic, Financial, and Satisfaction and IM-GM Coordination (as IVs)

\begin{tabular}{lllllll}
\hline DVs and IVs List & $\begin{array}{l}\text { F } \\
\text { values }\end{array}$ & $\begin{array}{l}\text { P-valu } \\
\text { es }\end{array}$ & R & $\begin{array}{l}\text { R } \\
\text { Square }\end{array}$ & $\begin{array}{l}\text { Adjusted } \\
\text { R Square }\end{array}$ & $\begin{array}{l}\text { Durbin } \\
\text { Watson }\end{array}$ \\
\hline Performance (via goodwill) * IM-GM & 4.866 & $\mathbf{0 . 0 0 0}$ & 0.374 & 0.140 & 0.111 & 1.450 \\
Performance (via strategic) * IM-GM & 9.873 & $\mathbf{0 . 0 0 0}$ & 0.498 & $\mathbf{0 . 2 4 8}$ & $\mathbf{0 . 2 2 3}$ & 1.422 \\
Performance (via financial )* IM-GM & 5.873 & $\mathbf{0 . 0 0 0}$ & 0.405 & 0.164 & 0.136 & 1.567 \\
Performance (via customer satisfaction) * IM-M & 6.834 & $\mathbf{0 . 0 0 0}$ & 0.431 & $\mathbf{0 . 1 8 6}$ & $\mathbf{0 . 1 5 9}$ & 1.567 \\
\hline
\end{tabular}

Table 16. ANOVA Coefficient's Values of IM-GM Coordination and FIP

\begin{tabular}{llllllll}
\hline Goodwill & $\mathbf{8}$ & $\mathbf{9}$ & $\mathbf{1 0}$ & $\mathbf{1 1}$ & $\mathbf{1 2}$ & $\mathbf{1 3}$ & $\mathbf{1 4}$ \\
\hline $\boldsymbol{B}$ Value & $\mathbf{0 . 1 6 9}$ & 0.033 & 0.048 & 0.126 & 0.080 & 0.079 & 0.062 \\
$\boldsymbol{P}$-Value & $\mathbf{0 . 0 3 6}$ & 0.651 & 0.556 & 0.171 & 0.259 & 0.313 & 0.369 \\
\hline Strategic & $\mathbf{8}$ & $\mathbf{9}$ & $\mathbf{1 0}$ & $\mathbf{1 1}$ & $\mathbf{1 2}$ & $\mathbf{1 3}$ & $\mathbf{1 4}$ \\
\hline B Value & $\mathbf{0 . 2 0 4}$ & 0.002 & 0.038 & $\mathbf{0 . 1 6 6}$ & 0.084 & 0.081 & 0.071 \\
$\boldsymbol{P}$-Value & $\mathbf{0 . 0 0 1}$ & 0.960 & 0.547 & $\mathbf{0 . 0 1 9}$ & 0.124 & 0.180 & 0.182 \\
\hline Financial & $\mathbf{8}$ & $\mathbf{9}$ & $\mathbf{1 0}$ & $\mathbf{1 1}$ & $\mathbf{1 2}$ & $\mathbf{1 3}$ & $\mathbf{1 4}$ \\
\hline B Value & 0.092 & 0.097 & $\mathbf{0 . 1 8 7}$ & 0.142 & 0.009 & $\mathbf{0 . 2 8 1}$ & 0.014 \\
$\boldsymbol{P}$-Value & 0.274 & 0.209 & $\mathbf{0 . 0 3 1}$ & 0.140 & 0.897 & $\mathbf{0 . 0 0 0}$ & 0.837 \\
\hline Satisfaction & $\mathbf{8}$ & $\mathbf{9}$ & $\mathbf{1 0}$ & $\mathbf{1 1}$ & $\mathbf{1 2}$ & $\mathbf{1 3}$ & $\mathbf{1 4}$ \\
\hline B Value & 0.099 & 0.045 & 0.102 & $\mathbf{0 . 1 5 0}$ & 0.046 & 0.105 & 0.025 \\
$\boldsymbol{P}$-Value & 0.130 & 0.452 & $\mathbf{0 . 1 3 2}$ & $\mathbf{0 . 0 4 7}$ & 0.426 & 0.100 & 0.647 \\
Note: $8-14=X 8-X 14$ items & as appeared in Appendix (B) & & & & & \\
\hline
\end{tabular}

In Table 17 there is a significant causality relationship between international marketing (IM) influence and IM-GM coordination as $P=0.000 \leq 0.05$. Therefore, hypothesis $(\boldsymbol{H} 3 \boldsymbol{b})$ is supported. In this perspective, the most remarkable things here are:

- The order of data entry process did not affect on its analysis, as Durbin-Watson test showed values $>$ 1.4 with all dependent variables, as shown in Table (17).

- The explanation powers of IM-GM coordination's magnitude on IM influence are low as " $R$ square" and "adjusted $R$ square" reported values less than 50 percent. These values are 20.6 , and 18.0 percent for " $R$ square" and "adjusted $R$ square" respectively.

- More specifically and using ANOVA coefficient values as in Table (18), only two items of the seven items 
of IM influence \{i.e. protecting one's functional turf (i.e. neighborhood) is considered to be a way of life between these functions. (X12) and the objectives pursued by one function are compatible with those of the other function (X13) have reported significant relationship with IM-GM coordination as $\boldsymbol{B}=0.235$, and 0.176 and $\boldsymbol{P}$-value $=0.000$ and $0.005 \leq 0.05)$.

Table 17. Multiple Regressions between IM Influence (as DV) and IM-GM Coordination (as, IVs)

\begin{tabular}{lllllll}
\hline DVs and IVs List & F & P-values & R & R Square & $\begin{array}{l}\text { Adjusted R } \\
\text { Square }\end{array}$ & $\begin{array}{l}\text { Durbin-W } \\
\text { atson }\end{array}$ \\
\hline VM-GM Coordination & 7.775 & $\mathbf{0 . 0 0 0}$ & 0.454 & 0.206 & 0.180 & 1.902 \\
\hline
\end{tabular}

Table 18. ANOVA Coefficient's Values for IM-GM Coordination (as, IVs)

\begin{tabular}{llllllll}
\hline IM-GM & $\mathbf{8}$ & $\mathbf{9}$ & $\mathbf{1 0}$ & $\mathbf{1 1}$ & $\mathbf{1 2}$ & $\mathbf{1 3}$ & $\mathbf{1 4}$ \\
\hline $\boldsymbol{B}$ Value & 0.005 & 0.100 & 0.031 & 0.005 & $\mathbf{0 . 2 3 5}$ & $\mathbf{0 . 1 7 6}$ & 0.002 \\
$\boldsymbol{P}$-Value & 0.927 & 0.096 & 0.634 & 0.941 & $\mathbf{0 . 0 0 0}$ & $\mathbf{0 . 0 0 5}$ & 0.966 \\
\hline
\end{tabular}

Note: $8-14=\mathrm{X} 8-\mathrm{X} 14$ items as appeared in Appendix (B).

In Table (19) there is a significant causality relationship between firm international performance (FIP) and IM influence as $P=0.000 \leq 0.05$. Therefore, hypothesis $(\boldsymbol{H} 4)$ is supported. In this perspective, the most remarkable things here are:

- The order of data entry process did not affect on the analysis of two variables, as Durbin-Watson test showed values $>1.4$. However, two other DVs (i.e. good well= 1.242 and strategic performance $=1.255$ ) reported values less than 1.4, as indicated at Table (19). This means the analysis of these specified variables affected by the data entry order, therefore if the data entry order changes might lead to different results in this perspective. A practice which not followed in the current research due to technical and time constrains.

- The explanation powers of bi-marketing interaction's magnitude on the four sub-performance indicators i.e. firm's goodwill, strategic performance, financial performance, and customer satisfaction are low as " $R$ square" and "adjusted $R$ square" reported values less than 50 percent. These values are 12.4, 19.6, 14.2, and 16.3 percent and 10.8, 18.1, 12.6, and 14.7 percent for " $R$ square" and "adjusted $R$ square" respectively.

- More specifically and using ANOVA coefficient values as in Table (20), firm's goodwill is affected by two items \{i.e. the functions performed by the IM function are generally considered to be more critical than others (X16) and the IM function is considered to be more influential than others (X19) $\}$ out of the four items of IM influence concept as $\boldsymbol{B}=0.155$ and 0.144 and $\boldsymbol{P}$-value $=0.050$ and $0.050 \leq 0.05$ ). Also, financial performance is affected by two items \{i.e. (X16) and IM tends to dominate other functions in decision making (X18) $\}$ out of the four items of IM influence, as $\boldsymbol{B}=0.208$ and 0.163 and $\boldsymbol{P}$-value $=0.013$ and $0.050 \leq 0.05$ ). For strategic performance, it is affected by only one item $\{$ i.e. (X16) $\}$ out of the four items of IM influence, as $\boldsymbol{B}$ $=0.233$ and $\boldsymbol{P}$-value $=0.000 \leq 0.05$ ). Finally, customer satisfaction is affected by only one item \{i.e. (X16) $\}$ out of the four items of IM influence, as $\boldsymbol{B}=0.199$ and $\boldsymbol{P}$-value $=0.002 \leq 0.05$ ).

Table 19. Multiple Regressions between Firm International Performance (FIP) (as DV) measured by Goodwill, Strategic, Financial, and Satisfaction and IM Influences (as, IVs)

\begin{tabular}{|c|c|c|c|c|c|c|}
\hline DVs and IVs List & $\begin{array}{l}\text { F } \\
\text { values }\end{array}$ & P-values & $\mathbf{R}$ & $\begin{array}{l}\text { R } \\
\text { Square }\end{array}$ & $\begin{array}{l}\text { Adjusted } \\
\text { R Square }\end{array}$ & Durbin-Watson \\
\hline Performance (via goodwill) * IM influences & 7.559 & 0.000 & 0.353 & 0.124 & 0.108 & 1.245 \\
\hline Performance (via strategic) * IM influences & 12.988 & 0.000 & 0.443 & 0.196 & 0.181 & 1.255 \\
\hline Performance (via financial )* IM influences & 8.828 & 0.000 & 0.377 & 0.142 & 0.126 & 1.762 \\
\hline Performance (via customer satisfaction) * IM influences & 10.351 & 0.000 & 0.404 & 0.163 & 0.147 & 1.438 \\
\hline
\end{tabular}


Table 20. ANOVA Coefficient's Values for IM Influence

\begin{tabular}{llllllllll}
\hline _Goodwill & $\mathbf{1 6}$ & $\mathbf{1 7}$ & $\mathbf{1 8}$ & $\mathbf{1 9}$ & Strategic & $\mathbf{1 6}$ & $\mathbf{1 7}$ & $\mathbf{1 8}$ & $\mathbf{1 9}$ \\
\hline B Value & $\mathbf{0 . 1 5 5}$ & 0.045 & 0.073 & $\mathbf{0 . 1 4 4}$ & $\boldsymbol{B}$ Value & $\mathbf{0 . 2 3 3}$ & 0.102 & 0.049 & 0.049 \\
$\boldsymbol{P}$-Value & $\mathbf{0 . 0 5 0}$ & 0.616 & 0.367 & $\mathbf{0 . 0 5 0}$ & $\boldsymbol{P}$-Value & $\mathbf{0 . 0 0 0}$ & 0.158 & 0.447 & 0.407 \\
\hline Financial & $\mathbf{1 6}$ & $\mathbf{1 7}$ & $\mathbf{1 8}$ & $\mathbf{1 9}$ & Satisfaction & $\mathbf{1 6}$ & $\mathbf{1 7}$ & $\mathbf{1 8}$ & $\mathbf{1 9}$ \\
\hline B Value & $\mathbf{0 . 2 0 8}$ & 0.175 & $\mathbf{0 . 1 6 3}$ & 0.125 & $\boldsymbol{B}$ Value & $\mathbf{0 . 1 9 9}$ & 0.124 & 0.058 & 0.017 \\
$\boldsymbol{P}$-Value & $\mathbf{0 . 0 1 3}$ & 0.069 & $\mathbf{0 . 0 5 0}$ & 0.113 & $\boldsymbol{P}$-Value & $\mathbf{0 . 0 0 2}$ & 0.099 & 0.381 & 0.777
\end{tabular}

Note: 16-19=X16-X19 items as appeared in Appendix (B)

In Table 21 there is a significant causality relationship between firm international performance (FIP) and international learning as $P=0.000 \leq 0.05$. Therefore, hypothesis $(\boldsymbol{H 5})$ is supported. In this perspective, the most remarkable things here are:

- $\quad$ The order of data entry process did not affect on its analysis, as Durbin-Watson test showed values $>1.4$ with all dependent variables but one (i.e. performance measured via good well $=1.365$ less than 1.4 ), as indicated at Table (21). This means the analysis of these specified variables were affected by the data entry order, therefore if the data entry order changes might lead to different results in this perspective. A practice which not followed in the current research due to technical and time constrains.

- The explanation powers of bi-marketing interaction's magnitude on the four sub-performance indicators i.e. firm's goodwill, strategic performance, financial performance, and customer satisfaction are low as " $R$ square" and "adjusted $R$ square" reported values less than 50 percent. These values are $23.8,38.8,26.7$, and 35.4 percent and 22.4, 37.6, 25.3, and 34.2 percent for " $R$ square" and "adjusted $R$ square" respectively.

- More specifically and using ANOVA coefficient values as in Table (22), firm's goodwill is affected by only one item \{i.e. the sense around here is that employee learning from international environment is an investment, not an expense (X55) $\}$ out of the four items of international learning concept as $\boldsymbol{B}=0.332$ and $\boldsymbol{P}$-value $=0.000 \leq 0.05)$. Meanwhile, financial performance is affected by two items $\{$ i.e. (X55) and "the basic values of our international selling process include learning from international environment as a key to improvement" (X56) $\}$ out of the four items of international learning concept, as $\boldsymbol{B}=0.223$ and 0.369 and $\boldsymbol{P}$-value $=0.020$ and $0.000 \leq 0.05)$. For strategic performance, it is affected by three items $\{$ i.e. $(\mathrm{X} 55),(\mathrm{X} 56)$, and "once we quit learning from international environment, we endanger our future" (X57) $\}$ out of the four items of international learning, as $\boldsymbol{B}=0.233,0.160$, and 0.144 and $\boldsymbol{P}$-value $=0.000,0.033$, and $0.022 \leq 0.05$ ). Finally, customer satisfaction is affected by two items \{i.e. (X55) and (X58) "we agree that our ability to learn from international environment is the key to improvement in our business" $\}$ out of the four items of international learning concept, as $\boldsymbol{B}=0.258$, and 0.133, and $\boldsymbol{P}$-value $=0.000$, and $0.45 \leq 0.05$ ).

Table 21. Multiple Regressions between Firm International Performance (FIP) (as DV) measured by Goodwill, Strategic, Financial, and Satisfaction and International Learning (as, IVs)

\begin{tabular}{|c|c|c|c|c|c|c|}
\hline DVs and IVs List & $\begin{array}{l}\text { F } \\
\text { Values }\end{array}$ & P-values & $\mathbf{R}$ & $\begin{array}{l}\text { R } \\
\text { Square }\end{array}$ & $\begin{array}{l}\text { Adjusted } \\
\text { R Square }\end{array}$ & Durbin-Watson \\
\hline Performance (via goodwill) * International learning & 16.608 & 0.000 & 0.488 & 0.238 & 0.224 & 1.365 \\
\hline Performance (via strategic) * International learning & 33.626 & 0.000 & 0.623 & 0.388 & 0.376 & 1.689 \\
\hline Performance (via financial )* International learning & 19.337 & 0.000 & 0.517 & 0.267 & 0.253 & 1.758 \\
\hline $\begin{array}{l}\text { Performance (via customer satisfaction) * International } \\
\text { learning }\end{array}$ & 29.150 & 0.000 & 0.595 & 0.354 & 0.342 & 1.911 \\
\hline
\end{tabular}

Table 22. ANOVA Coefficient's Values for International Learning

\begin{tabular}{|c|c|c|c|c|c|c|c|c|c|}
\hline Goodwill & 55 & 56 & 57 & 58 & Strategic & 55 & 56 & 57 & 58 \\
\hline B Value & 0.332 & 0.099 & 0.127 & 0.060 & B Value & 0.233 & 0.160 & 0.144 & 0.119 \\
\hline$P$-Value & 0.000 & 0.328 & 0.135 & 0.481 & $P$-Value & 0.000 & 0.033 & 0.022 & 0.060 \\
\hline Financial & 55 & 56 & 57 & 58 & Satisfaction & 55 & 56 & 57 & 58 \\
\hline B Value & 0.223 & 0.369 & 0.037 & 0.090 & B Value & 0.258 & 0.131 & 0.121 & 0.133 \\
\hline$P$-Value & 0.020 & 0.000 & 0.670 & 0.307 & $P$-Value & 0.000 & 0.095 & 0.066 & 0.045 \\
\hline
\end{tabular}

Note: $55-58=X 55-X 58$ items as appeared in Appendix (B) 
In Table (23) there is a significant causality relationship between firm international performance (FIP) and international innovativeness as $P=0.000 \leq 0.05$. Therefore, hypothesis $(\boldsymbol{H 6})$ is supported. In this perspective, the most remarkable things here are:

- The order of data entry process did not affect on its analysis, as Durbin-Watson test showed values $>$ 1.4 with all dependent variables, as indicated at Table (23).

- The explanation powers of international innovativeness' magnitudes on the four sub-performance indicators i.e. firm's goodwill, strategic performance, financial performance, and customer satisfaction are low as " $R$ square" and "adjusted $R$ square" reported values less than 50 percent. These values are 22.3, 37.3, 21.1, and 30.7 percent and 20.4, 35.8, 19.2, and 29.1 percent for " $R$ square" and "adjusted $R$ square" respectively.

- More specifically and using ANOVA coefficient values as in Table (24), firm's goodwill is affected by two items \{i.e. management actively seeks innovative ideas (X45), and people are compensated for new ideas that work (X47) $\}$ out of the five items of innovativeness concept as $\boldsymbol{B}=0.175$, and 0.175 , and $\boldsymbol{P}$-value $=0.043$, and $0.028 \leq 0.05)$. Also, financial performance is affected by two items \{i.e (X45) and innovation perceived as too risky is not resisted (X48)\} out of the five items of innovativeness concept, as $\boldsymbol{B}=0.266$ and 0.170 and $\boldsymbol{P}$-value $=0.004$ and $0.022 \leq 0.05)$. For strategic performance, it is affected by four items $\{$ i.e. $(\mathrm{X} 45)$, innovation is readily accepted in program/ project management (X46), (X47), and (X48)\} out of the five items of innovativeness concept, as $\boldsymbol{B}=0.220,0.156,0.132$ and 0.149 and $\boldsymbol{P}$-value $=0.000,0.013$, and 0.025 , and 0.004 $\leq 0.05)$. Finally, customer satisfaction is affected by three items $\{$ i.e. (X45), (X46), and (X47)\} out of the four items of innovativeness concept, as $\boldsymbol{B}=0.194,0.213$ and 0.135 and $\boldsymbol{P}$-value $=0.004,0.001$, and $0.032 \leq 0.05$ ).

Table 23. Multiple Regressions between Firm International Performance (FIP) (as DV) measured by Goodwill, Strategic, Financial, and Satisfaction and International Innovativeness (as, IVs)

\begin{tabular}{|c|c|c|c|c|c|c|}
\hline DVs and IVs List & $\begin{array}{l}\text { F } \\
\text { values }\end{array}$ & P-values & $\mathbf{R}$ & $\begin{array}{l}\text { R } \\
\text { Square }\end{array}$ & $\begin{array}{l}\text { Adjusted } \\
\text { R } \\
\text { Square } \\
\end{array}$ & DurbinWatson \\
\hline Performance (via goodwill) * International innovativeness & 12.121 & 0.000 & 0.472 & 0.223 & 0.204 & 1.325 \\
\hline Performance (via strategic) $*$ International innovativeness & 25.158 & 0.000 & 0.611 & 0.373 & 0.358 & 1.441 \\
\hline Performance (via financial )* International innovativeness & 11.302 & 0.000 & 0.459 & 0.211 & 0.192 & 1.676 \\
\hline $\begin{array}{l}\text { Performance (via customer satisfaction) } * \text { International } \\
\text { innovativeness }\end{array}$ & 18.762 & 0.000 & 0.554 & 0.307 & 0.291 & 1.647 \\
\hline
\end{tabular}

Table 24. ANOVA Coefficient's Values for International Innovativeness

\begin{tabular}{llllllllllll}
\hline Goodwill & $\mathbf{4 4}$ & $\mathbf{4 5}$ & $\mathbf{4 6}$ & $\mathbf{4 7}$ & $\mathbf{4 8}$ & Strategic & $\mathbf{4 4}$ & $\mathbf{4 5}$ & $\mathbf{4 6}$ & $\mathbf{4 7}$ & $\mathbf{4 8}$ \\
\hline B Value & 0.071 & $\mathbf{0 . 1 7 5}$ & 0.055 & $\mathbf{0 . 1 7 5}$ & 0.126 & B Value & 0.021 & $\mathbf{0 . 2 2 0}$ & $\mathbf{0 . 1 5 6}$ & $\mathbf{0 . 1 3 2}$ & $\mathbf{0 . 1 4 9}$ \\
$\boldsymbol{P}$-Value & 0.413 & $\mathbf{0 . 0 4 3}$ & 0.510 & $\mathbf{0 . 0 2 8}$ & 0.071 & $\boldsymbol{P}$-Value & 0.737 & $\mathbf{0 . 0 0 0}$ & $\mathbf{0 . 0 1 3}$ & $\mathbf{0 . 0 2 5}$ & $\mathbf{0 . 0 0 4}$ \\
\hline Financial & $\mathbf{4 4}$ & $\mathbf{4 5}$ & $\mathbf{4 6}$ & $\mathbf{4 7}$ & $\mathbf{4 8}$ & Satisfaction & $\mathbf{4 4}$ & $\mathbf{4 5}$ & $\mathbf{4 6}$ & $\mathbf{4 7}$ & $\mathbf{4 8}$ \\
\hline B Value & 0.011 & $\mathbf{0 . 2 6 6}$ & 0.029 & 0.131 & $\mathbf{0 . 1 7 0}$ & B Value & 0.021 & $\mathbf{0 . 1 9 4}$ & $\mathbf{0 . 2 1 3}$ & $\mathbf{0 . 1 3 5}$ & 0.060 \\
$\boldsymbol{P}$-Value & 0.900 & $\mathbf{0 . 0 0 4}$ & 0.746 & 0.122 & $\mathbf{0 . 0 2 2}$ & $\boldsymbol{P}$-Value & 0.752 & $\mathbf{0 . 0 0 4}$ & $\mathbf{0 . 0 0 1}$ & $\mathbf{0 . 0 3 2}$ & 0.271 \\
Note: $44-48=X 44-X 48$ items as appeared in Appendix (B) & & & & & &
\end{tabular}

In Table 25 there is a significant causality relationship between firm international performance (FIP) and international entrepreneurial orientation as $P=0.000 \leq 0.05$. Therefore, hypothesis $(\boldsymbol{H} 7)$ is supported. In this perspective, the most remarkable things here are:

- $\quad$ The order of data entry process did not affect on its analysis, as Durbin-Watson test showed values $>1.4$ with all dependent variables as indicated at Table (25).

- The explanation powers of international entrepreneurial orientation's magnitude on the four sub-performance indicators i.e. firm's goodwill, strategic performance, financial performance, and customer satisfaction are low as " $R$ square" and "adjusted $R$ square" reported values less than 50 percent. These values are 33.8, 47.6, 30.2, and 45.1 percent and $29.5,44.3,25.7$, and 41.6 percent for " $R$ square" and "adjusted $R$ square" respectively.

- More specifically and using ANOVA coefficient values as in Table (26), firm's goodwill is affected by only two items \{i.e. our firm's strategy for competitive advantage is based on our thorough understanding of our 
cross border customer needs (X31), and when confronted with international decision-making involving uncertainty, my firm typically adopts a bold, aggressive posture (X42) \} out of the eleventh items of entrepreneurial concept as $\boldsymbol{B}=0.214$ and 0.183 and $\boldsymbol{P}$-value $=0.025$, and $0.009 \leq 0.05$ ). Also, financial performance is affected by only one item \{i.e. all our functions (not just marketing and sales) are responsive to, and integrated in, serving international target markets $(\mathrm{X} 30)\}$ out of the eleventh items of entrepreneurial concept, as $\boldsymbol{B}=0.339$ and $\boldsymbol{P}$-value $=0.000 \leq 0.05$ ). For strategic performance, it is affected by two items $\{$ i.e. (X30), and top managers at my firm have a strong tendency for high-risk projects/products in international markets (X40) $\}$ out of the eleventh items of entrepreneurial concept, as $\boldsymbol{B}=0.233$, and 0.098 and $\boldsymbol{P}$-value $=$ 0.000 , and $0.045 \leq 0.05$ ). Finally, customer satisfaction is affected by four items \{i.e. (X30), our firm's market strategies are to a great extent driven by our understanding of possibilities for creating value for cross border customers (X34), (X40), and (X42) $\}$ out of the eleventh items of entrepreneurial concept, as $\boldsymbol{B}=0.200,0.151$, 0.138 , and 0.112 and $\boldsymbol{P}$-value $=0.001,0.012,0.006$ and $0.037 \leq 0.05$ ).

Table 25. Multiple Regressions between Firm International Performance (FIP) (as DV) measured by Goodwill, Strategic, Financial, and Satisfaction and International Entrepreneurial Orientation (as, IVs)

\begin{tabular}{|c|c|c|c|c|c|c|}
\hline DVs and IVs List & $\begin{array}{l}\text { F } \\
\text { Values } \\
\end{array}$ & P-values & $\mathbf{R}$ & $\begin{array}{l}\text { R } \\
\text { Square }\end{array}$ & $\begin{array}{l}\text { Adjusted } \\
\text { R Square }\end{array}$ & Durbin-Watson \\
\hline Performance (via goodwill) * Entrepreneurial orientation & 7.9342 & 0.000 & 0.581 & 0.338 & 0.295 & 1.486 \\
\hline Performance (via strategic) * Entrepreneurial orientation & 14.160 & 0.000 & 0.690 & 0.476 & 0.443 & 1.694 \\
\hline Performance (via financial )* Entrepreneurial orientation & 6.746 & 0.000 & 0.550 & 0.302 & 0.257 & 1.641 \\
\hline $\begin{array}{l}\text { Performance (via customer satisfaction) * Entrepreneurial } \\
\text { orientation }\end{array}$ & 12.813 & 0.000 & 0.672 & 0.451 & 0.416 & 1.904 \\
\hline
\end{tabular}

Table 26. ANOVA Coefficient's Values for Entrepreneurial Orientation

\begin{tabular}{|c|c|c|c|c|c|c|c|c|c|c|c|c|c|}
\hline Goodwill & 30 & 31 & 32 & 33 & 34 & 35 & 36 & 37 & 38 & 39 & 40 & 41 & 42 \\
\hline B Value & 0.111 & 0.214 & 0.046 & 0.060 & 0.037 & 0.058 & 0.068 & 0.061 & 0.040 & 0.040 & 0.060 & 0.010 & 0.183 \\
\hline P-Value & 0.182 & 0.025 & 0.639 & 0.410 & 0.633 & 0.467 & 0.407 & 0.453 & 0.569 & 0.598 & 0.362 & 0.886 & 0.009 \\
\hline Strategic & 30 & 31 & 32 & 33 & 34 & 35 & 36 & 37 & 38 & 39 & 40 & 41 & 42 \\
\hline B Value & 0.233 & 0.043 & 0.041 & 0.007 & 0.073 & 0.078 & 0.051 & 0.037 & 0.038 & 0.0835 & 0.098 & 0.038 & 0.076 \\
\hline$P$-Value & 0.000 & 0.532 & 0.571 & 0.891 & 0.203 & 0.182 & 0.393 & 0.538 & 0.470 & 0.136 & 0.045 & 0.486 & 0.138 \\
\hline Financial & 30 & 31 & 32 & 33 & 34 & 35 & 36 & 37 & 38 & 39 & 40 & 41 & 42 \\
\hline B Value & 0.339 & 0.052 & 0.119 & 0.023 & 0.046 & 0.002 & 0.106 & 0.006 & 0.013 & 0.124 & 0.079 & 0.102 & 0.036 \\
\hline P-Value & 0.000 & 0.613 & 0.270 & 0.766 & 0.588 & 0.980 & 0.238 & 0.937 & 0.862 & 0.134 & 0.274 & 0.211 & 0.633 \\
\hline Satisfaction & 30 & 31 & 32 & 33 & 34 & 35 & 36 & 37 & 38 & 39 & 40 & 41 & 42 \\
\hline B Value & 0.200 & 0.091 & 0.048 & 0.080 & 0.151 & 0.069 & 0.018 & 0.072 & 0.017 & 0.035 & 0.138 & 0.005 & 0.112 \\
\hline$P$-Value & 0.001 & 0.208 & 0.526 & 0.152 & 0.012 & 0.255 & 0.769 & 0.245 & 0.745 & 0.538 & 0.006 & 0.928 & 0.037 \\
\hline
\end{tabular}

In Table 27 there is a significant causality relationship between firm international performance (FIP) and international interaction as $P=0.000 \leq 0.05$. Therefore, hypothesis $(\boldsymbol{H B})$ is supported. In this perspective, the most remarkable things here are:

- The order of data entry process did not affect on its analysis, as Durbin-Watson test showed values $>1.4$ with two dependent variables, as indicated at Table (27). However, the order of data entry process did affect on its analysis, as Durbin-Watson test reported values 1.386 and 1.293 less than 1.4 with goodwill and strategic performances respectively.

- The explanation powers of international interactive magnitudes on the four sub-performance indicators i.e. firm's goodwill, strategic performance, financial performance, and customer satisfaction are weak as " $R$ square" and "adjusted $R$ square" reported values less than 50 percent. These values are $0.253,0.246,0.072$, and 0.216 percent and $0.239,0.231,0.054$, and 0.201 percent for " $R$ square" and "adjusted $R$ square" respectively.

- More specifically and using ANOVA coefficient values as in Table (28), firm's goodwill is affected by three items \{i.e. X50 "are easy to talk to cross-border customers", X51 "like to socialize during sales interactions", and "are interested in them as person, not just a salespersons" X53 \} out of the four items of international interaction concept as $\boldsymbol{B}=0.272,0.218$, and 0.220, and $\boldsymbol{P}$-value $=0.000,0.022$, and $0.017 \leq 0.05$ ). 
For strategic performance, it is affected only one item \{i.e. (X53\} out of the four items of international interaction concept, as $\boldsymbol{B}=0.322$, and $\boldsymbol{P}$-value $=0.000 \leq 0.05$ ). Finally, customer satisfaction is affected by only one item \{i.e. (X53) $\}$ out of the four items of international interaction concept, as $\boldsymbol{B}=0.327$, and $\boldsymbol{P}$-value $=$ $0.000 \leq 0.05)$.

Table 27. Multiple Regressions between Firm International Performance (FIP) (as DV) measured by Goodwill, Strategic, Financial, and Satisfaction and Interaction (as, IVs)

\begin{tabular}{llllllll}
\hline DVs and IVs List & F & P-values & R & $\begin{array}{l}\text { R } \\
\text { Square }\end{array}$ & $\begin{array}{l}\text { Adjusted } \\
\text { R Square }\end{array}$ & Durbin-Watson \\
& values & & & & . & \\
\hline Performance (via goodwill) * IM influences & 18.037 & $\mathbf{0 . 0 0 0}$ & 0.503 & 0.253 & 0.239 & $\mathbf{1 . 3 8 6}$ \\
Performance (via strategic) * IM influences & 17.293 & $\mathbf{0 . 0 0 0}$ & 0.496 & $\mathbf{0 . 2 4 6}$ & $\mathbf{0 . 2 3 1}$ & $\mathbf{1 . 2 9 3}$ \\
Performance (via financial)* IM influences & 4.1360 & $\mathbf{0 . 0 0 3}$ & 0.269 & 0.072 & 0.054 & 1.552 \\
Performance (via customer satisfaction) * IM influences & 14.611 & $\mathbf{0 . 0 0 0}$ & 0.464 & 0.216 & 0.201 & 1.520 \\
\hline
\end{tabular}

Table (28) ANOVA Coefficient's Values for Interaction

\begin{tabular}{llllllllll}
\hline _Goodwill & $\mathbf{5 0}$ & $\mathbf{5 1}$ & $\mathbf{5 2}$ & $\mathbf{5 3}$ & Strategic & $\mathbf{5 0}$ & $\mathbf{5 1}$ & $\mathbf{5 2}$ & $\mathbf{5 3}$ \\
\hline B Value & $\mathbf{0 . 2 7 2}$ & $\mathbf{0 . 2 1 8}$ & 0.106 & $\mathbf{0 . 2 2 0}$ & $\boldsymbol{B}$ Value & 0.117 & 0.022 & 0.068 & $\mathbf{0 . 3 2 2}$ \\
$\boldsymbol{P}$-Value & $\mathbf{0 . 0 0 0}$ & $\mathbf{0 . 0 2 2}$ & 0.320 & $\mathbf{0 . 0 1 7}$ & $\boldsymbol{P}$-Value & 0.070 & 0.774 & 0.438 & $\mathbf{0 . 0 0 0}$ \\
\hline Financial & $\mathbf{5 0}$ & $\mathbf{5 1}$ & $\mathbf{5 2}$ & $\mathbf{5 3}$ & Satisfaction & $\mathbf{5 0}$ & $\mathbf{5 1}$ & $\mathbf{5 2}$ & $\mathbf{5 3}$ \\
\hline B Value & 0.084 & 0.034 & 0.060 & 0.174 & $\boldsymbol{B}$ Value & 0.071 & 0.008 & 0.053 & $\mathbf{0 . 3 2 7}$ \\
$\boldsymbol{P}$-Value & 0.358 & 0.758 & 0.629 & 0.109 & $\boldsymbol{P}$-Value & 0.286 & 0.920 & 0.560 & $\mathbf{0 . 0 0 0}$ \\
Note: $50-53=X 50-X 53$ items as appeared in Appendix (B) & & & & & \\
\hline
\end{tabular}

\subsection{Results'Discussion}

Firm's international performance (FIP) is believed to be affected by set of variables that ought to be considered for better market position in foreign markets. These set of variables are bi marketing interaction, IM-GM cooperation, IM influence, international learning, innovativeness, entrepreneurial orientations, and international interaction. Specifically, these set of variables affect positively firms' reputation, level of customer satisfaction, level of achieving strategic and financial objectives in foreign markets.

More specifically, strategic and financial international performances are affected by the constructive interactions and cooperation between its two main subsections i.e. local and exporting marketing teams. That cooperation could be in forms of sharing the resources i.e. data bases, customer calls, and other materialistic resources with each other, as the current study stresses the importance of such constrictive cooperation, via these tools, in long run. Also, that constrictive cooperation helps build the international goodwill and enhance customer satisfaction levels.

Therefore, companies seeking enhancing their goodwill and strategic performance in foreign markets have to have easy going relationship and harmony amongst team members of both general marketing (GM) and international marketing (IM). The same perquisite i.e. harmonized team is needed for enhancing the customer satisfaction and financial performance. In that harmonized team, each and every team member consider team' objectives as his/her objective and eager to achieve and perceiving compatibility amongst these objectives as revealed in the current study. That leads to enhance the level of team's cohesiveness as each team member consider protecting one's functional turf or neighborhood a way of life between GM and IM functions.

Performance and international orientations (i.e. learning, innovativeness, and entrepreneurial) are crucial for long term success. More specifically, perceiving international learning activities as investment not expense, perceiving the lessons to be learned from each foreign market, perceiving quit learning from foreign environment endanger firm future, and reaming vigilant and in a receptive state of mind in foreign markets are considered the key success factors for performance enhancement as revealed in the current study..

For innovativeness, companies ought to seek innovative ideas and bear the required risk to enhance their performances in foreign markets. To reach that level, employees to be compensated for new ideas they innovate. For entrepreneurial, the starting point is the better understanding of customer needs in these foreign markets, working with obvious team spirit not just inside marketing and sales departments but within all supporting departments. Besides that, the support of top management for foreign market team is crucial as well. 
Finally, performance is affected by international interaction with customers of foreign markets. That interaction reflects on easy to talk to cross-border customers, and showing interest to them.

\subsection{Conclusion and Recommendations}

The study's results revealed that firm's international performance (FIP) is affected by the model's proposed variables. Consequently, those firms with ambitious objectives, in foreign markets, ought to consider these variables to enhance their image, to achieve their strategic objectives, to better satisfy their foreign market customers, and to better achieve their financial objectives. Explicitly, these variables are bi marketing daily interaction amongst marketing personnel i.e. local and export, enhancing the cooperation level between the activities of international marketing and general marketing, maintain international marketing influence across firm's structure, adopt wise international learning orientation strategy, adopt effective international innovativeness strategy, encourage practical international entrepreneurial strategy and international interaction. However, the study results did not approve the existence of significant relationship between FIP and study demographics i.e. business type, ownership, experience, and number of employees.

The study added new building blocks in international marketing literature by figuring out these variables behind enhancing the international performance in foreign markets. Also, the study responded positively to literature's growing demands for more studies in this particular filed, i.e. international performance, with much focus on international activities and performance (e.g. Ali et al., 2014; Leonidas and Bradley, 2010, Douglas and Craig, 1992; and Albaum and Peterson, 1984). Cavusgil and Nevin, (1981) were pioneers in hinting and urging for more international performance studies to bridge the gap in this perspective. Annex, the current study results goes hand in hand with Verhoef et al., (2011); and Moorman and Rust, (1999) for supporting their claims regarding the existence of positive relationship between IM influences and FIP. Meanwhile, the current study results contradict with Merlo and Auh, (2009); and Verhoef and Leeflang, (2009) in this perspective i.e. IM influences and FIP.

As the magnitude of the approved relationships are weak (i.e. values of adjusted $R$ are less than 50 percent), other researchers are invited to explore other sets of variables rather than those tested in the current study to get a clear and comprehensive insights on international performance concept.

\section{References}

Aaby, N. E., \& Slater, S. F. (1989). Managerial Influences on Export Performance: a Review of the Empirical Literature 1978-88. International Marketing Review, 6(4), 53-68.

Albaum, G., \& Peterson, R. A. (1984). Empirical research in international marketing: 1976-1982. Journal of International Business Studies, Spring/Summer, 161-73. https://doi.org/10.1057/palgrave.jibs.8490479

Ali, E. A., Halit, K., \& Hayat, A. (2014). Standardization and Adaptation of International Marketing Mix Activities: A Case Study. Procedia-Social and Behavioral Sciences, 150, 609-618. https://doi.org/10.1016/j.sbspro.2014.09.080

Anderson, R. C., \& Reeb, D. (2003). Founding-Family Ownership and Firm Performance: Evidence from the S\&P 500. The Journal of Finance, LVIII(3), 1301-1328. https://doi.org/10.1111/1540-6261.00567

Bae, J., \& Lawler, J. J. (2000). Organizational and HRM strategies in Korea: Impact on firm performance in an emerging economy. The Academy of Management Journal, 43(3), 502-517. https://doi.org/10.2307/1556407

Baker, W. E., \& Sinkula, J. M. (1999). The synergistic effect of market orientation on performance. Journal of the Academy of Marketing Science, 27(4), 411-427. https://doi.org/10.1177/0092070399274002

Becker, B. E., Huselid, M. A., Pickus, P. S., \& Spratt, M. F. (1997). HR as a source of shareholder value: Research and recommendations. Human Resource Management, 36(1), 39-47. https://doi.org/10.1002/(SICI)1099-50X(199721)36:1<39::AID-HRM8>3.0.CO;2-X

Bennett, R., \& Savani, S. (2004). Managing conflict between marketing and other functions within charitable organizations. The Leadership \& Organization Development Journal, 25(2), 180-200. https://doi.org/10.1108/1437730410521840

Bilkey, W. J. (1978). An attempted integration of the literature on the export behaviour of firms. Journal of International Business Studies, 9(1), 33-46. https://doi.org/10.1057/palgrave.jibs.8490649

Blesa, A., \& Ripolles, M. (2008). The influence of marketing capabilities on international performance. International Marketing Review, 25(6), 651-673. https://doi.org/10.1108/02651330810915574

Bradley, F. (2005). International Marketing Strategy fifth edition. England: Person Education Limited. 
Bryman, A., \& Cramer, D. (1999). Quantitative Data analysis with SPSS Release 8 for Windows: A Guide for Social Scientists. Routledge, London. https://doi.org/10.4324/9780203459621

Cadogan, J. W., Diamantopoulos, A., \& de Mortgages, C. P. (1999). A measure of export market orientation: scale development and cross-cultural validation. Journal of International Business Studies, 30(4), 689-707. https://doi.org/10.1057/palgrave.jibs.8490834

Cadogan, J. W., Sundqvist, S., Salminen, R. T., \& Puumalainen, K. (2005). Export marketing, interfunctional interactions, and performance consequences. Journal of the Academy of Marketing Science, 33(4), 520-535. https://doi.org/10.1177/0092070305276148

Calantone, R., Cavusgil, T., \& Zhao, Y. (2002). Learning orientation, firm innovation, and firm performance. Industrial Marketing Management, 31(6), 515-524. https://doi.org/10.1016/S0019-8501(01)00203-6

Cappelli, P., \& Neumark, D. (2001). Do "high-performance" work practices improve establishment level outcomes? Industrial and Labor Relations Review, 54(4), 737-775. https://doi.org/10.2307/ 2696111.

Cavusgil, S. T. (1998). Perspectives: knowledge development in international marketing. Journal of International Marketing, 6(2), 103-12.

Cavusgil, S. T., \& Nevin, J. P. (1981). State of the art in International Marketing: an assessment. In Enis, B.M. and Roering, K. P. (Eds.), Review of Marketing 1981 (pp. 195-216).

Chan, Y., Huff, S., \& Copeland, D. G. (1998). Assessing Realized Information Systems Strategy. Journal of Strategic Information Systems, 6, 273-298.

Codita, R. (2011). International marketing standardization: A literature review. In Codita, R. (Ed.), Contingency Factors of Marketing-Mix Standardization.

Cohen, S. G., \& Bailey, D. E. (1997). What makes teams work: Group effectiveness research from the shop floor to the executive suite. Journal of Management, 23(3), 239-290. https://doi.org/10.1177/014920639702300303

Collins, C. J., \& Clark, K. D. (2003). Strategic human resource practices, top management team social networks, and firm performance: The role of human resource practices in creating organizational competitive advantage. The Academy of Management Journal, 46(6), 740-751. https://doi.org/10.2307/30040665

Covin, J. J., \& Slevin, D. P. (1991). A conceptual model of entrepreneurship as firm behavior. Entrepreneurship Theory and Practice, 16(1), 7-25.

Czinkota, M. R., \& Ronkainen, I. A., (2012). International marketing (10th ed.). England.

Czinkota, M. R., \& Ronkainen, I. A. (2007). International Marketing, Thomson, Mason, OH.

Douglas, S. P., \& Craig, C. S. (1992). Advances in international marketing. International Journal of Research in Marketing, 9(4), 291-318. https://doi.org/10.1016/0167-8116(92)90002-3

d'Arcimoles, C. H. (1997). Human resource policies and company performance: A quantitative approach using longitudinal data. Organization Studies, 18, 857-874. https://doi.org/10.1177/017084069701800508

Dahringer, L. D., \& Muhlbacher, H. (1991). International Marketing a Global Perspective. McGraw-Hill Inc., USA.

Day, G. S. (1994). The capabilities of market-driven organizations. Journal of Marketing, 58(4), 37-52. https://doi.org/10.2307/1251915

Dechow, P. M. (1994). Accounting earnings and cash flows as measures of firm performance; The role of $\begin{array}{llllll}\text { accounting accruals. Journal of Accounting, \& Economics, } 18, & 3-42 .\end{array}$ https://doi.org/10.1016/0165-4101(94)90016-7

Delery, J. E., \& Doty, D. H. (1996). Modes of theorizing in strategic human resource management: Tests of universalistic, contingency, and configurational performance predictions. The Academy of Management Journal, 39(4), 802-835. https://doi.org/10.2307/256713

Dewar, R. D., Whetten, D. A., \& Boje, D. (1980). An examination of the reliability and validity of the Aiken and Hage scales of centralization, formalization, and task routines. Administrative Science Quarterly, 25(1), 120-128. https://doi.org/10.2307/2392230

Dimitratos, P., \& Plakoyiannaki, E. (2003). Theoretical foundations of an international entrepreneurial culture. Journal of International Entrepreneurship, 1(2), 187-215. https://doi.org/10.1023/A:1023804318244 
Doole, I., \& Lowe, R., (2008). International Marketing Strategy analysis, development and implementation (5th ed.). British Library Cataloguing-in-Publication.

Douglas, S. P., \& Craig, C. S. (1992). Advances in international marketing. International Journal of Research in Marketing, 9(4), 291-318. https://doi.org/10.1016/0167-8116(92)90002-3

El-Ragal, A. (2001). Building DSS Using Knowledge Discovery in Database Techniques: Applied to Admissions and Registration Functions. Unpublished PhD Thesis, Business School, University of Plymouth, UK.

Engelen, A. (2011). Which department should have more influence on organization-level decisions? A strategy-dependent analysis. Journal of Strategic Marketing, 19(3), 229-254. https://doi.org/10.1080/0965254X.2011.557739

Etzioni, A. (1964). Modern organizations. Upper Saddle River, NJ: Prentice Hall.

Farley, J., \& Wind, Y. (1980). International Marketing: the neglect continues. Journal of Marketing, 44(2), 5-6.

Foster, J. (2001). Data Analysis Using SPSS for Windows (2nd ed.). Sage Ltd., London.

Ghauri, P., \& Cateora, P. (2011). International Marketing (2nd ed.). Edinburgh Business School, Great Britain.

Ghiselli, E., Campbell, J., \& Zedeck, S. (1981). Measurement Theory for the Behavioral Sciences. W. H. Freeman, San Francisco, USA.

Griffin, A., \& Hauser, R. (1996). Integrating R\&D-marketing: a review and analysis of the literature. Journal of Product Innovation Management, 13(3), 191-215. https://doi.org/10.1111/1540-5885.1330191

Guan, J., \& Ma, N. (2003). Innovative capability and export performance of Chinese firms. Technovation, 23(9), 737-747. https://doi.org/10.1016/S0166-4972(02)00013-5

Harris, L. C., Ogbonna, E., \& Goode, M. H. (2008). Intra-functional conflict: An investigation of antecedent factors in marketing functions. European Journal of Marketing, 42(3/4), 453-476. https://doi.org/10.1108/03090560810853011

Hills, G. E. (1999). An inaugural commentary for the journal of research in marketing and entrepreneurship. Journal of Research in Marketing and Entrepreneurship, 1(1), 5-7.

Hult, G., Tomas, M., Nichols, E. L. Jr., Giunipero, L. C., \& Hurley, R. F. (2000). Global organizational learning in the supply chain: a low versus high learning study. Journal of International Marketing, 8(3), 61-83. https://doi.org/10.1509/jimk.8.3.61.19628

Hult, G. T. M., Charles, C. S., \& Destan, K. (2003). The role of entrepreneurship in building cultural competitiveness in different organizational types. Journal of Management, 29(3), 401-426. https://doi.org/10.1016/S0149-2063(03)00017-5

Hurley, R. F., \& Hult, G. T. M. (1998). Innovation, market orientation, and organizational learning: an integration and empirical examination. Journal of Marketing, 62(33), 42-54. https://doi.org/10.2307/1251742

Huselid, M. A. (1995). The impact of human resource management practices on turnover, productivity, and corporate financial performance. The Academy of Management Journal, 38(3), 635-672. https://doi.org/10.2307/256741

Jain, S. (1999). International marketing management. Thomson South-Western.

Jaworski, B. J., \& Kohli, A. K. (1993). Market orientation: antecedents and consequences. Journal of Marketing, 57(3), 53-70. https://doi.org/10.2307/1251854

Keil, M., Mann, J., \& Rai, A. (2000). Why Software Projects Escalate: An Empirical Analysis and Test of Four Theoretical Models. MIS Quarterly, 24(4), 631-664.

Kim, K., Park, J. H., \& Prescott, J. E. (2003). The global integration of business functions: a study of multinational businesses in integrated global industries. Journal of International Business Studies, 34(4), 327-344. https://doi.org/10.1057/palgrave.jibs.8400035

Kirbach, M., \& Schmiedebery, C. (2006). Innovation and export performance: adjustment and remaining differences in East and West German manufacturing.

Kline, P., (1997). An Easy Guide for Factor Analysis. Routledge, London.

Knight, G. A. (2001). Entrepreneurship and strategy in the international SME. Journal of International Management, 7(3), 155-171. https://doi.org/10.1016/S1075-4253(01)00042-4 
Lam, L. W., \& White, L. P. (1998). Human resource orientation and corporate performance. Human Resource Development Quarterly, 9(4), 351-364. https://doi.org/10.1002/hrdq.3920090406

Lee, J., \& Miller, D. (1999). People matter: Commitment to employees, strategy and performance in Korean firms. Strategic Management Journal, 20(6), 579-593. https://doi.org/10.1002/(SICI)1097-0266(199906)20:6<579::AID-SMJ37>3.0.CO;2-C

Lee, M. B., \& Chee, Y. (1996). Business strategy, participative human resource management and organizational performance: The case of South Korea. Asia Pacific Journal of Human Resources, 34, 77-94. https://doi.org/10.1177/103841119603400105

Leonidas C. and Bradley R. B.,(2010). Assessing the contribution of leading mainstream marketing journals to the international marketing discipline. International Marketing Review, 27(5), 491-518. https://doi.org/10.1108/02651331011076563

Leonidas, C., Leonidou, B. R., Barnes, S. S., \& Constantine, S. K. (2010). Assessing the contribution of leading mainstream marketing journals to the international marketing discipline. International Marketing Review, 27(5), 491-518. https://doi.org/10.1108/02651331011076563

Li, T., \& Cavusgil, S. T. (1995). A classification and assessment of research streams in international marketing. International Business Review, 4(3), 251-77. https://doi.org/10.1016/0969-5931(95)00009-O

Lotayif, M. (2004). GATS Impacts on Entry Modes and Defensive Marketing Strategies in the Egyptian Banking Sector. Published PhD Thesis, Business School, University of Plymouth, UK.

Lotayif, M. (2017). Causality Relationships between Main Branding Variables and International Marketing Strategy: Evidence from MNCs in GCC Markets. International Journal of Business and Management (IJBM), 12(1), 140-158.

Lotayif, M. (2015a). University Industry (U-I) Relationship: Evidence from an Egyptian University. International Journal of Business and Management (IJBM), 10(4), 113-122. https://doi.org/10.5539/ijbm.v10n4p113.

Lotayif, M. (2005). Entry Modes and Different Marketing Strategies Models", In \{Kiefer Lee and Steve Carter, Global Marketing Management, 176-180.

Lotayif, M. (2015b). The Components of Marketing Strategies Making (MSM) and the Relationships with Strategy Antecedents and Consequences: Evidences from Egypt. The Business Review, Cambridge (BRC), 2, (December), 27-136.

Lotayif, M. (2014). Causality Relationship for Selection Variables of Brand Creation and Brand Acquisition as Expansion Strategies: Evidence from Egypt. The Journal of American Academy of Business, Cambridge (JAABC), 19(2), 287-285.

Lotayif, M. (2016). Selection Factors of Market Segments and Porter's Generic Marketing Strategies: Evidence from an Emerging GCC Market. International Journal of Business and Management (IJBM), 11(1), 199-215. https://doi.org/10.5539/ijbm.v11n1p199

Malhotra, N. K. (1993). Marketing Research An Applied Orientation. Prentice-Hall, Inc., New Jersey, USA.

McFarland, R. G., Challagalla, G. N., \& Shervani, T. A. (2006). Influence tactics for effective adaptive selling. Journal of Marketing, 70(4), 103-117. https://doi.org/10.1509/jmkg.70.4.103

Menon, A., Bharadwaj, S. G., Adidam, P. T., \& Edison, S.W. (1999). Antecedents and consequences of marketing strategy making: a model and a test. Journal of Marketing, 63(2), 18-40. https://doi.org/10.2307/1251943

Merlo, O. (2011). The influence of marketing from a power perspective. European Journal of Marketing, 45(7/8), 1152-1171. https://doi.org/10.1108/03090561111137651

Merlo, O., \& Auh, S. (2009). The effects of entrepreneurship, market orientation, and marketing subunit influence on firm performance. Marketing Letters, 20(3), 295-311. https://doi.org/10.1007/s11002-009-9072-7

Miesenbo"ck, K. J. (1988). Small businesses and exporting: a literature review. International Small Business Journal, 6(1), 42-61. https://doi.org/10.1177/026624268800600204

Montemayor, E. F. (1996). Congruence between pay policy and competitive strategy in high performance firms. Journal of Management, 22, 889-908. https://doi.org/10.1016/S0149-2063(96)90041-0

Moorman, C., \& Rust, R. T. (1999). The role of marketing. Journal of Marketing, 63(4), 180-197. https://doi.org/10.2307/1252111 
Morris, M. H., Schindehutte, M., \& LaForge, R. W. (2002). Entrepreneurial marketing: a construct for integrating emerging entrepreneurship and marketing perspectives. Journal of Marketing Theory and Practice, 10(4), 1-19. https://doi.org/10.1080/10696679.2002.11501922

Narver, J. C., \& Slater, S. F. (1990). The effect of a market orientation on business profitability. Journal of Marketing, 54(4), 20-35. https://doi.org/10.2307/1251757

Nunnally, J. C. (1978). Psychometric Theory (2nd ed.). McGraw-Hill, New York.

O'Sullivan, D., \& Abela, A. V. (2007). Marketing performance measurement ability and firm performance. Journal of Marketing, 71(2), 79-83. https://doi.org/10.1509/jmkg.71.2.79

Omar, O. (2008). International Marketing, Palgrave Macmillan Publication.

Ortuzar, J. D., \& Willumsen, L. G., (1994). Modelling Transport. John Wiley and Sons Ltd, New York.

Oviatt, B. M., \& McDougall, P. P. (2005). Defining international entrepreneurship and modeling the speed of internationalization. Entrepreneurship Theory and Practice, 29(5), 537-553. https://doi.org/10.1111/j.1540-6520.2005.00097.x

Pan, Y., \& Tse, D. K. (2000). The Hierarchical Model of Market Entry Modes. Journal of International Business Studies, 31(4), 535-555.

Papadopoulos, N., \& Martı'n, O. M. (2010). Toward a model of the relationship between internationalization and export performance. International Business Review, 19(4), 388-406. https://doi.org/10.1016/j.ibusrev.2010.02.003

Pelham, A. M., \& Wilson, D. T. (1996). A longitudinal study of the impact of market structure, firm structure, strategy, and market orientation culture on dimensions of small-firm performance. Journal of the Academy of Marketing Science, 24(1), 27-43. https://doi.org/10.1007/BF02893935

Peterson, R. A., \& Jolibert, A. J. P. (1995). A meta-analysis of country-of-origin effects. Journal of International Business Studies, 26(4), 883-900. https://doi.org/10.1057/palgrave.jibs.8490824

Ravichandran, T., \& Rai, A. (2000). Quality Management in Systems Development: An Organizational System Perspective. MIS Quarterly, 24(3), 381-415.

Richard, O. C., \& Johnson, N. B. (2001). Strategic human resource management effectiveness and firm performance. International Journal of Human Resource Management, 12(2), 299-310. https://doi.org/10.1080/09585190121674

Robin L. W., Dorothy, E. L., \& Gary, G., (2008). A Model of Conflict, Leadership, and Performance in Virtual Teams.

Rust, J., \& Golombok, S. (1999). Modern Psychometrics (2nd ed.). Routledge, London.

Saravanan, R., \& Rao, K. S. P. (2007). Measurement of Service Quality from the Customer's Perspective-An Empirical Study. Total Quality Management, 18(4), 435-449.

Sepulveda, F. L. (2010). The entrepreneurial orientation of rapidly internationalizing service firms and its link to international operations. competitive paper, 18th Annual High Technology Small Firms Conference, Enschede.

Shoham, A., Ruvio, A., Vigoda-Gadot, E., \& Schwabsky, N. (2008). A nomological model of organization innovativeness: a cross cultural test in the public sector. working paper.

Sinkula, J. M. (1994). Market information processing and organizational learning. Journal of Marketing, 58(1), 35-45. https://doi.org/10.2307/1252249

Slater, S. F., \& Narver, J. C. (1995). Market orientation and the learning organization. Journal of Marketing, 59(3), 63-74. https://doi.org/10.2307/1252120

Stanley, J. P. (1999). International marketing: An assessment. International Marketing Review, 16(1), 8-17. https://doi.org/10.1108/02651339910257601

Stewart, D. W. (2002). Getting published: reflections of an old editor. Journal of Marketing, 66(3), 1-6. https://doi.org/10.1509/jmkg.66.4.1.18520

Stodnick, M., \& Pamela, R. (2008). Using SERVQUAL to Measure the Quality of the Classroom Experience. Decision Sciences Journal of Innovative Education, 6(1), 115-134.

Teo, T., \& King, W., (1996). Assessing The Impact of Integrating Business Planning and IS Planning. Information 
and Management, 30, 309-321.

Terpstra, V., \& Sarathy, R. (1991). International Marketing. Dryden Press, USA.

Tesar, G. (1984). Marketing abroad forges ahead but education in international area lags. Marketing News, 11, $7-12$.

Theodosiou, M. A., \& Leonidou, L. C. (2003). Standardization versus adaptation of international marketing strategy: An integrative assessment of the empirical research. International Business Research, 12(2), 141-71. https://doi.org/10.1016/s0969-5931(02)00094-x

Thompson, J. D. (1967). Organizations in action: Social science bases of administrative theory. New York, NY: McGraw-Hill.

Verhoef, P. C., \& Leeflang, P. S. H. (2009). Understanding the marketing department's influence within the firm. Journal of Marketing, 73(2), 14-37. https://doi.org/10.1509/jmkg.73.2.14

Verhoef, P. C., Leeflang, P. S. H., Reiner, J., Natter, M., Baker, W., Grinstein, A., Morrison, P., \& Saunders, J. (2011). A cross-national investigation into the marketing department's influence within the firm: toward initial empirical generalizations. Journal of International Marketing, 19(3), 59-86. https://doi.org/10.1509/jimk.19.3.59

Verlegh, P. W. J., \& Steenkamp, J. B. E. M. (1999). A review and meta-analysis of country-of-origin research. Journal of Economic Psychology, 20(5), 521-46. https://doi.org/10.1016/S0167-4870(99)00023-9

Vern, T. (2000). The millennium and international marketing. International Marketing Review, 17(1), 15-18. https://doi.org/10.1108/02651330010314687

Wang, X., \& Yang, Z. (2008). A meta-analysis of effect sizes in international marketing experiments. International Marketing Review, 25(3), 276-291. https://doi.org/10.1108/02651330810877216

Wind, Y., \& Perlmutter, H. (1977). On the identification of frontier issues in multinational marketing. Columbia Journal of World Business, Winter, 131-139.

Wonnacott, T. H., \& Wonnacott, R. J. (1990). Introductory Statistics for Business and Economics. John Wiley and Sons Inc.

Yutchman, E., \& Seashore, S. (1967). A system resource approach to organizational effectiveness. American Sociological Review, 32, 891-903. https://doi.org/10.2307/2092843

Zou, S., Taylor, C. R., and Osland, G. E. (1998). The EXPERF scale: a cross-national generalized export performance measure. Journal of International Marketing, 6(3), 37-58.

\section{Appendix (B)}

(A) Demographical Variables

1. Type of Business (BUS)

a. Commercial ( )

b. Industrial ( )

c. Service ( )

d. Others ( )

2. Type of Ownership (OWN)

a. Private ( )

b. Public and Governmental ( )

3. Business international Experience (EXP)

a. One year or less ( )

b. 5 years or less ( )

c. 10 years or less ( )

d. 15 years or less ( )

e. 20 years or less ( )

f. More than 20 years or less ( )

4. Business Size (SIZE)

a. Large (more than 500 employees) ( )

b. Medium (between 100-500 employees)( )

c. Small (less than 100 employees) ( ) 
d. Missing

( )

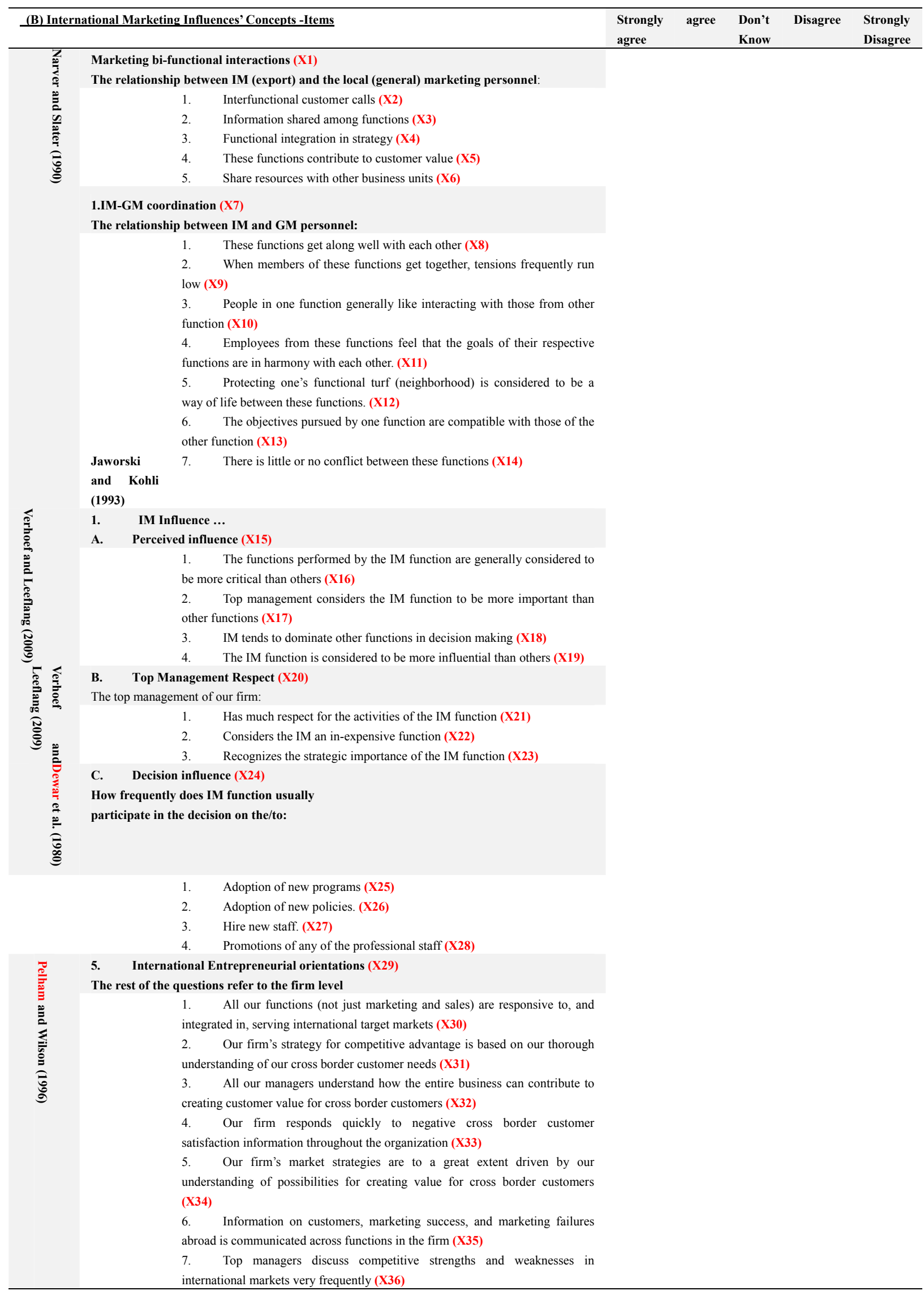




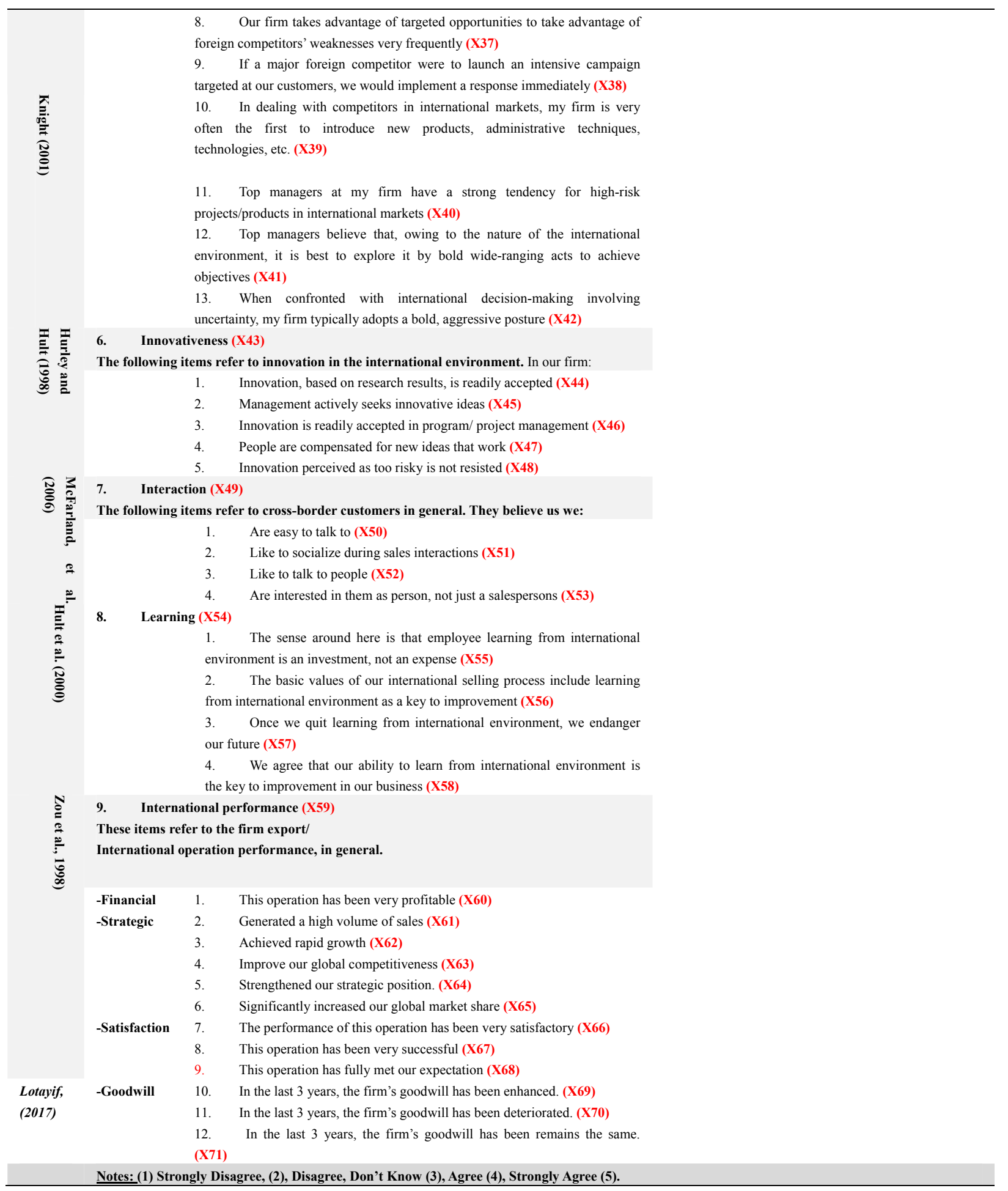

\section{Copyrights}

Copyright for this article is retained by the author(s), with first publication rights granted to the journal.

This is an open-access article distributed under the terms and conditions of the Creative Commons Attribution license (http://creativecommons.org/licenses/by/4.0/). 